\title{
Growth and Cycles of the Italian Economy Since 1861: The New Evidence
}

\author{
Fabio Clementi · Marco Gallegati • \\ Mauro Gallegati
}

Received: 19 September 2011 / Accepted: 20 November 2013 / Published online: 5 December 2014 (C) Società Italiana degli Economisti (Italian Economic Association) 2014

\begin{abstract}
Based on a newly-available large set of historical national accounts, the paper revisits the main features of economic growth and cycles in Italy for the postUnification period 1861-2011. Alongside the structural changes in growth dynamics, the main sources of output and productivity growth are identified. As regards the analysis of the underlying cyclical component, a business cycle chronology is first established and then both the specific patterns of individual cycles and the co-movements of output with key macroeconomic variables are investigated. In the 150 years since its political Unification, Italy's economic growth was mainly propelled by consumption and investments, whereas on the supply side the industry and services sectors were by far the main contributors, also because of the positive effect of labour reallocation to nonfarm activities. Over the same period, Italy experienced approximately 20 business cycles of varying duration and amplitude. Output fluctuations were dominated by the short-term variability of agricultural production before World War II and by fluctua-
\end{abstract}

Earlier drafts of this paper were presented at the study day in honour of Guido M. Rey "L'economia italiana: modelli, misurazione e nodi strutturali" (Università degli Studi Roma Tre, 5 March 2010) and the conference "Sviluppo economico e benessere" (Università Politecnica delle Marche, Ancona, 5 and 6 November 2010). We are grateful to all the participants for their useful comments. We also thank Alberto Baffigi for his precious help with the historical sources used, and Claire Giordano and Francesco Zollino for sharing their data with us upon request. Last, but not least, we thank two anonymous reviewers for their thorough review and highly valuable comments and suggestions, which significantly contributed to improving the quality of the paper. The usual caveats apply.

F. Clementi $(\bowtie)$

Dipartimento di Scienze Politiche, della Comunicazione e delle Relazioni Internazionali, Università degli Studi di Macerata, Piazza Strambi 1, 62100 Macerata, Italy e-mail: fabio.clementi@unimc.it

Marco Gallegati · Mauro Gallegati

Dipartimento di Scienze Economiche e Sociali, Università Politecnica delle Marche,

Piazzale R. Martelli 8, 60121 Ancona, Italy 
tions of the industry sector thereafter. The cyclical behaviour exhibited by aggregate demand components conforms quite well to that evidenced in the standard international business cycle literature, although some exceptions arise in the pre-World War II years.

Keywords Italy $\cdot$ National accounts $\cdot$ Growth and fluctuations

JEL Classification $\quad \mathrm{N} 13 \cdot \mathrm{N} 14$

\section{Introduction}

Italy has a solid and long tradition of studies dealing with the issue of reconstructing national accounts in the post-Unification period. The first set of historical national accounts from 1861 to 1956, due to the National Institute for Statistics (ISTAT 1957), was revised and improved by a group of researchers of the University of Ancona under the supervision of Fuà (1969). Maddison (1991) proposed a revision of the GDP series for the period 1861-1989 by lowering the initial levels of the ISTATVitali GDP series, and then Rossi et al. (1993) reconstructed the GDP series from the expenditure side for the period 1890-1990 using the new benchmark for 1911 and the new estimates provided, respectively, by the Bank of Italy (Golinelli and Monterastelli 1990; Rey 1991). Recently, Fenoaltea (2005a, b, 2006) has produced, for the period between national Unification and World War I, the first entirely new estimates of Italian aggregate GDP since ISTAT-Vitali by combining Federico (2003) series for agriculture with his own series for industries and services. Finally, Baffigi (2013) has provided new GDP series, together with supply and demand side estimates, covering the 150 years after Italy's political Unification as a part of the " 150 anni" national accounts project that includes the Bank of Italy, ISTAT and the University of Rome "Tor Vergata" — as well as academics from other institutions. ${ }^{1}$

The availability of historical macroeconomic time series has favoured a proliferation of studies, especially in recent years, on the nature and causes of business cycle fluctuations $^{2}$ and-in a historical perspective - on growth in Italy. ${ }^{3}$ As a result, in the last two decades the knowledge about the historical patterns of Italian economy over such a long time span has considerably improved. From this point of view, the availability of new data provides the researcher with the opportunity to look at old facts and interpretations in new ways, and to answer the question to what extent these new estimates provide contrasting results about growth and cycles with respect to those presented in the previous literature, especially in the pre-World War II period.

\footnotetext{
1 For a critical assessment of the historical sources and methods used to obtain the new estimates, see Baffigi (2014).

2 See, for instance, Ardeni and Gallegati (1991, 1994a, b), Onofri et al. (1992), Chiarini (1994), Fiorito and Kollintzas (1994), Giannini et al. (1995), Ancona and Bonato (1996), Gallegati (1996), Schlitzer (1996), Stanca (1996), Checchi et al. (1997), Gaffeo and Gallegati (1997), Gallegati and Stanca (1998) and Delli Gatti et al. (2003, 2005).

3 In addition to Fuà (1969, 1981), see Ciocca and Toniolo (1976), Toniolo (1978, 1988), Zamagni (1993), Ciocca (1994), Federico (1994), Ciocca (2007) and Zamagni (2007).
} 
In this paper we revisit the Italian economic growth and cycles in the postUnification period using the new historical accounts presented in Baffigi (2013) for the period 1861-2011. In particular, we analyze whether the revised estimates provide new evidence as to the presence and number of structural changes in GDP growth that can suggest a different alternative interpretation of the phases of Italy's long-run economic growth, especially with regard to the interpretation that traces back Italy's economic development to the beginning of the nineteenth century. Specifically, following the recent literature supporting the view that macroeconomic time series, and GDP in particular, can be represented by stationary fluctuations around a (deterministic) segmented trend (e.g. Rappoport and Reichlin 1989), we test for multiple structural breaks at unknown dates in the trend function of GDP growth rate as suggested by Bai and Perron (1998, 2003). Moreover, since the new dataset also provides us with new estimates for both the supply and demand sides, this paper presents an analysis of the impact of these revisions to the overall pattern of the various supply and demand components' contributions to real growth.

As regards the analysis of the underlying cyclical component, we take into account both the classical and modern definitions of business cycle, where the first analyzes the specific patterns of individual cycles and the latter the co-movements between GDP and different key macroeconomic variables. Although most macroeconomists share the real business cycle (RBC) view that the "business cycles are all alike" (Lucas 1977), we try to go beyond this approach by integrating modern RBC analysis with a detailed description of individual phases and cycles according to the National Bureau of Economic Research (NBER) traditional approach. ${ }^{4}$ The aim of our methodology is to provide empirical evidence on regularities and discontinuities in economic fluctuations and to reconsider the hypothesis of business cycles similarity of the predominant view. In particular, following the modern definition of business cycle,,$^{5}$ after isolating the underlying cyclical component corresponding to fluctuations of approximate length between 1.5 and 8 years, we analyze the empirical regularities observed in the comovements among different aggregative time series. Moreover, following the Burns and Mitchell (1946) classical definition of business cycle analysis, which suggests to look at the characteristics of each individual cycle and phase in terms of duration, amplitude and steepness, we also check whether the revisions alter the key features of business cycle fluctuations, including the dating of turning points.

The paper is organized as follows. Section 2 describes the new dataset and provides a brief comparison with previous estimates. The long run dynamics of Italian economic growth is analyzed in Sect. 3 by identifying structural breaks in GDP growth rate, along with the contribution of the various supply and demand components to economic growth. Section 4 presents the results of the analysis of the cyclical component of Italian GDP using both the classical and modern definitions of business cycle. Finally, Sect. 5 concludes.

\footnotetext{
4 In addition to the two above referred approaches, it is worth mentioning the quantitative-analytical cycleby-cycle analysis based on the cliometric approach to economic history advocated by Temin (1998), which has been applied to Italian data by Delli Gatti et al. (2003, 2005).

5 The "[...] repeated fluctuations about trend" and the regularities "[...] observed [...] in the co-movements among different aggregative time series" (Lucas 1977).
} 


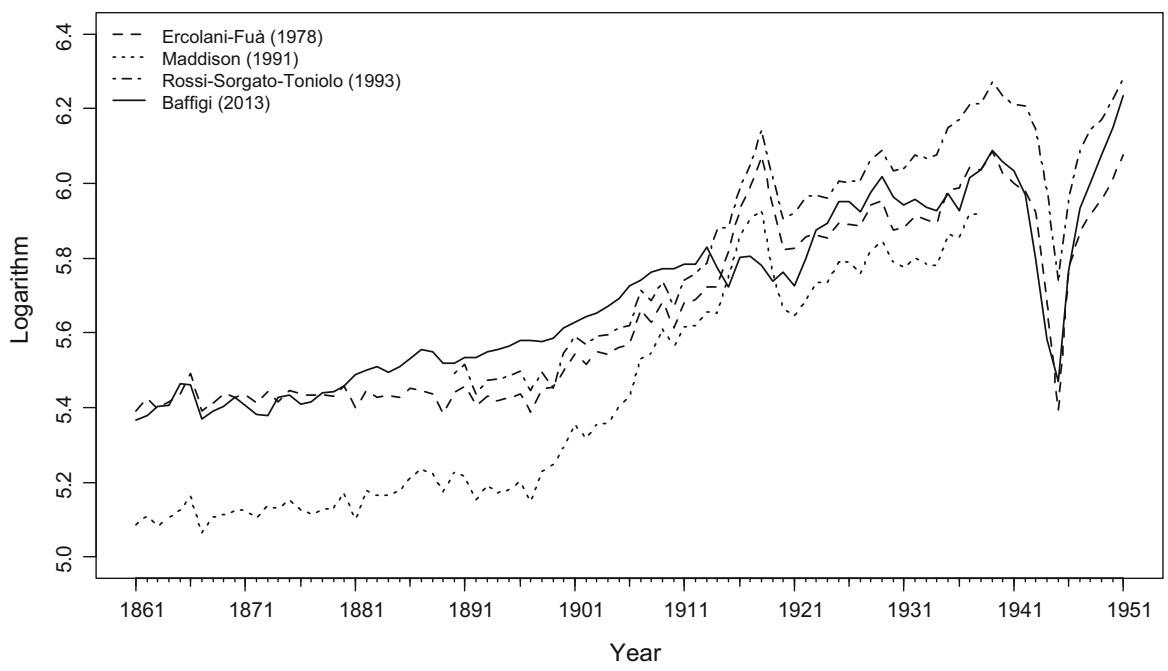

Fig. 1 GDP per capita at constant prices, 1861-1951 (millions of 1913 euros). Source Authors' own calculations using Ercolani (1978), Maddison (1991), Rossi et al. (1993) and Baffigi (2013) estimates

\section{The New Dataset: A Comparison with Previous Estimates}

The new series of Italian GDP upon which the analysis carried out in the following pages relies has introduced important changes with respect to previous estimates. As it can be visually perceived in Fig. 1, at least three significant differences are worth mentioning here that can add insight to the knowledge of both the long-term trend and the cyclical fluctuations of the Italian economy since Unification. ${ }^{6}$

First, compared to what was implied in previous reconstructions the new series embeds a pattern of more regular GDP along the five decades following Italy's Unification: while the GDP time series of Ercolani (1978), ${ }^{7}$ Maddison (1991) and Rossi et al. (1993) show a sudden and sharp acceleration in the pace of growth around the end of the nineteenth century, after the roughly stagnant decades of early post-Unification Italy, with the new estimates this discontinuity looks much less marked-though still visible on the eve of the Giolittian era-and the first forty years of life of the newly born Italian Kingdom are now viewed as a phase of slight but significant growth.

Furthermore, as noted by Broadberry (2005), previous GDP time series depicted World War I as a period of very large increase in Italy's output, which is difficult to parallel with the performance of other countries during the war years. In the same

\footnotetext{
6 For the ease of comparison, all the series in the figure have been expressed in euros and converted into 1913 prices. The time period has been limited to 1861-1951 so as to highlight the main differences occurring between the new GDP estimates and the previous ones - the Maddison (1991) series ends in 1938, as for 1938-1951 it is practically the same with the Ercolani (1978) one, whereas the Rossi et al. (1993) GDP estimates are available only since 1890 . For a more detailed illustration of the differences between the new GDP series and earlier estimates we refer the reader to Baffigi (2013).

7 Paolo Ercolani is the author of the statistical section containing the national accounts time series used in the preparation of the book edited by Fuà (1978).
} 
period the new GDP series follows instead a much more moderate path, as adjustments were made to incorporate the new estimates of value added in the services sector by Battilani et al. (2012) — who especially revised earlier estimates of general government value added — and De Bonis et al. (2012) — who contributed with a study on the financial sector.

Finally, earlier GDP estimates have been widely recognized as unable to capture the true extent of the Great Depression in Italy: the drop in economic activity in the years immediately after 1929 appears indeed to be relatively contained compared to many other European countries (see e.g. Mattesini and Quintieri 1997; Felice and Carreras 2012). Conversely, the new GDP series, based on the hitherto unexplored Giugliano (2011) industrial value added estimates, suggests that the decline in Italy's output was stronger (and lasted longer) than previously believed. Also, according to the new reconstruction the recovery to get back on trend takes now some more years to come.

Apart from data on GDP, the new set of Italy's historical national accounts also provides us with supply and demand side reconstructions. For the supply side, value added series at factor cost for three high levels of sectoral aggregation (agriculture, industry and services) are used ${ }^{8}$ for the demand side, the main time series are consumption (public and private), investments (including inventories variation) and the difference between external uses (exports of goods and services) and external sources (imports of goods and services). Some other time series analysed in the present paper, especially concerning the labour market and including employment and wage data, are instead derived from Broadberry et al. (2011) and Giordano and Zollino (2012). ${ }^{9}$

All series are expressed as chained 2005 euros on the basis of the current boundaries for the whole 1861-2011 period. ${ }^{10}$ In most cases, if not explicitly stated otherwise, these series have been scaled to per capita levels using the resident population data at the beginning of the year (Baffigi 2013) and converted to logarithms.

\section{The Long-Term Growth of the Italian Economy}

Figure 2 summarises the new series relative to GDP per capita at constant prices, expressed in log-levels.

\footnotetext{
8 Although value added estimates with a lower sectoral detail are provided, the only disaggregation level that is taken into consideration in our analysis is the one that distinguishes value added for public administration from value added for other (private) services. However, due to a classification consistency problem, this degree of sectoral detail is only available for the 1861-1970 period. Furthermore, the different treatment of the value of financial intermediation services before and after 1970 implies that in the 1861-1970 estimates one has to deduct this measure from the sum of sectoral values added in order to obtain GDP, while in the 1861-2011 block of estimates GDP is exactly equal to the sum of sectoral values added. We refer the reader to Baffigi (2013, pp. 161-162) for a more detailed illustration of the differences between the 1861-1970 and 1861-2011 blocks of estimates.

9 The data used by Broadberry et al. (2011) are publicly available at http://www.bancaditalia.it/statistiche/ storiche/LABCAP150-1.0.xls, while the original data from the study of Giordano and Zollino (2012) were kindly provided by the authors.

10 GDP implicit price deflator data can be found in the worksheet "Tab_03" of the accompanying Excel file (http://www.bancaditalia.it/statistiche/storiche/Data_Na150-1.1.xls) made available by Baffigi (2013).
} 


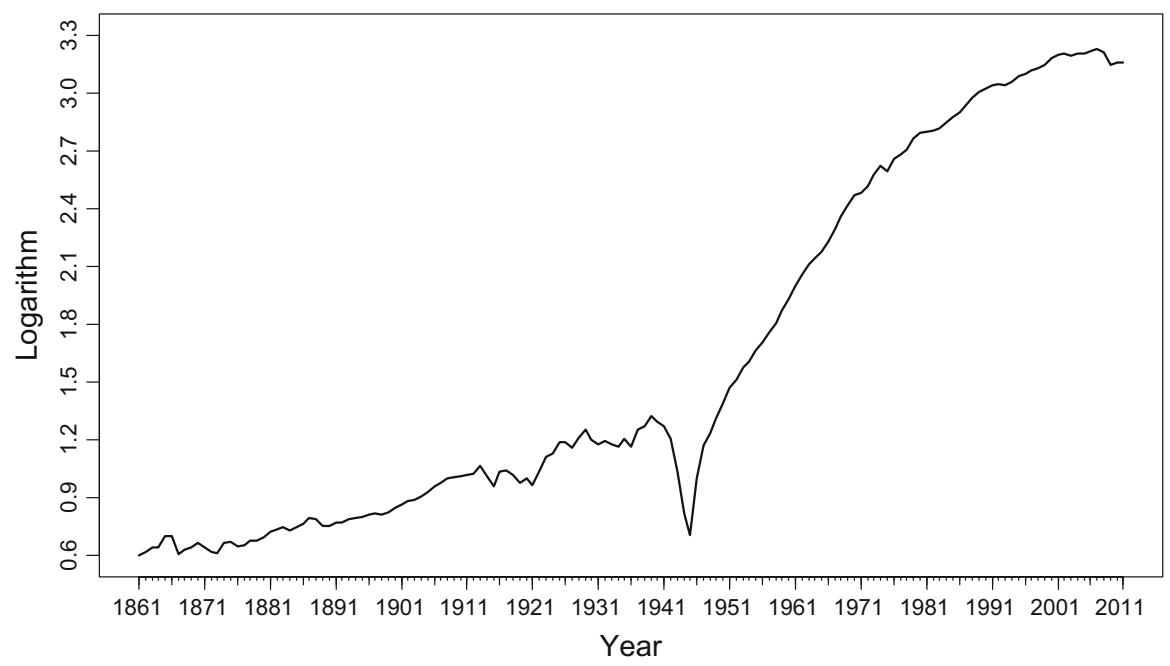

Fig. 2 GDP per capita at constant prices, 1861-2011 (thousands of 2005 euros). Source Authors' own calculations using Baffigi (2013) estimates

It can be interpreted as an approximation of Italy's long-run growth since the time of its political Unification in 1861. What emerges clearly from the figure is the non-linear trend characterizing the development process of the country over the period 18612011 as a whole: since the end of World War II, Italian GDP per capita experienced an intense growth acceleration whose intensity began to decline only around the time of the first oil shock in 1973, while in the previous ninety years (1861-1951) it had just doubled the initial GDP level, which attained a peak value only on the eve of Italy's intervention in World War II (Baffigi 2013, p. 165).

In order to disentangle the different structural character and different dynamics of Italy's development process, we perform a structural change analysis of the growth rates of GDP per capita over the whole 150-year period using the procedure proposed by Bai and Perron $(1998,2003)$, henceforth BP. ${ }^{11}$ A key feature of the methodology developed by these authors is that it allows us to test for multiple breaks at unknown dates. The model considered here is the multiple linear regression model with $m$ breaks (or, equivalently, $m+1$ growth regimes)

$$
g_{t}^{Y}=\beta_{j}+u_{t}, \quad t=T_{j-1}+1, \ldots, T_{j}, \quad j=1, \ldots, m+1,
$$

where $T_{0}=0$ and $T_{m+1}=T$ by convention ( $T$ is the sample size). In other words, within the growth regime $j$ the annual growth rate of GDP per capita $g_{t}^{Y}$ equals the regime-specific mean growth rate $\beta_{j}$ plus a stationary error term $u_{t}$, which may have

\footnotetext{
11 The same procedure, but operating on partly different sources of data, was also applied by Clementi et al. (2012). For an application to the same dataset, see instead Baffigi et al. (2013). However, in the latter case the results are not directly comparable with those presented in the main text, as the method of Bai and Perron is applied to the levels of the GDP series, rather than to its growth rates, and the GDP itself is not expressed in per capita terms.
} 


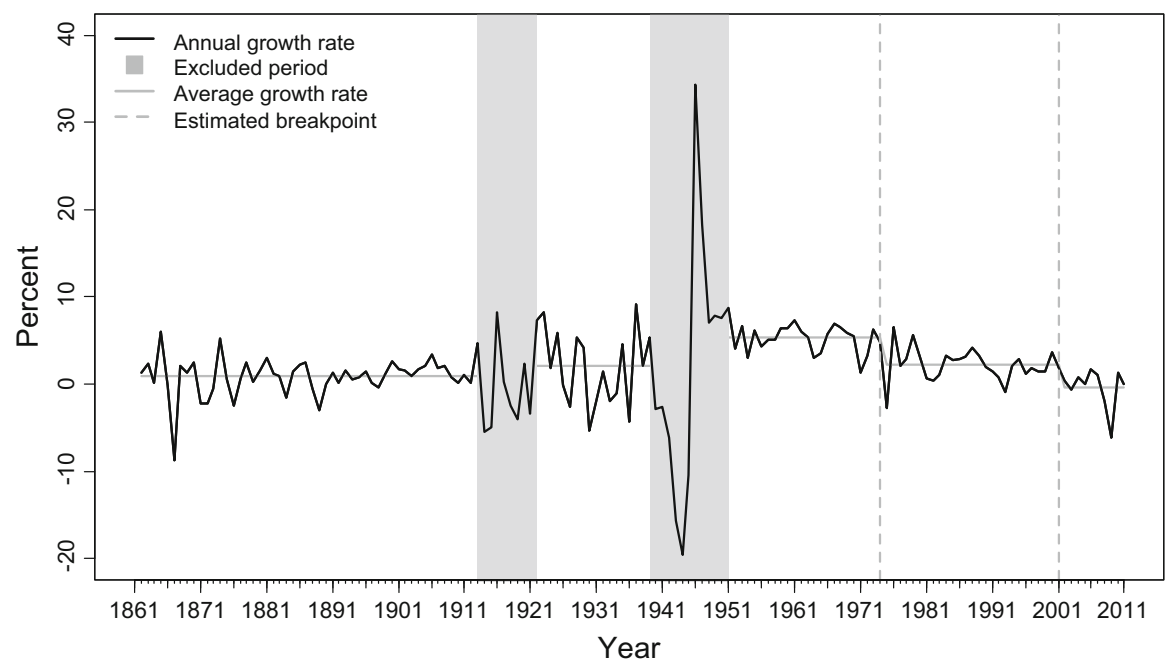

Fig. 3 Structural breaks in GDP growth of the Italian economy, 1862-2011. Source Authors' own calculations using Baffigi (2013) estimates

a different distribution across regimes. The goal of the analysis is to determine the optimal number and location of the structural break points $T_{j}, j=1, \ldots, m$, by minimizing the within-regime sums of squares. By default, our implementation of BP's technique derives the appropriate number of breaks as the one achieving the lowest Bayesian information criterion score. ${ }^{12}$

The results can be visualized in Fig. 3, which shows the growth rates of GDP per capita at constant prices throughout the period under consideration (black solid line) along with the estimated break points (grey dashed lines) and the regime-specific means in each resulting data segment (grey solid lines). ${ }^{13}$

As can be seen, no structural breaks were found in any of the liberal (1862-1913) or Fascist (1922-1939) periods between Unification and $1951,{ }^{14}$ while the era of

\footnotetext{
12 When implementing the BP's procedure for structural change, the minimum fraction of observations $\varepsilon$ (or, equivalently, the minimum number of observations $h$ ) allocated to any growth regime over which the search for break points is conducted is a parameter to be fixed by the researcher. To ensure that growth transitions are not confounded with business cycles, for our data the search utilizes a parameter of $\varepsilon=0.15$, corresponding to the minimal size of $h=15$ yearly observations; this amounts to allowing simultaneous calculation for up to $m=5$ breaks. The technique suggested by BP has been implemented in a unified way in the package strucchange (Zeileis et al. 2002, 2003; Zeileis and Kleiber 2005) for the statistical software R (http://www.R-project.org/), which is the one upon which we rely in the present study.

13 The two World Wars periods 1914-1921 and 1940-1950, marked as shaded areas in the figure, have been excluded from calculations in order to avoid significant reductions in power of the test.

14 Ciccarelli and Fenoaltea (2007) and Clementi et al. (2012), with the former applying different statistical methods for detecting structural change, point instead to the existence of a single break located at the turn of the nineteenth century. Although this statistical evidence is not of course sufficient reason to revive the older debate on the "take-off" of the historical literature, the new GDP series, by sharply reducing the turn-off century increase in the economy's growth rate, especially in per capita terms, casts severe doubts on the older view that Italy's economy "took off” in the early twentieth century.
} 
Table 1 Italy's economic performance, 1862-2011

\begin{tabular}{|c|c|c|c|c|c|c|}
\hline & \multicolumn{2}{|c|}{ Population } & GDP & Value added ${ }^{\mathrm{a}}$ & Employment & Real wages \\
\hline $1862-1913$ & \multicolumn{2}{|c|}{0.68} & 0.92 & 0.89 & 0.69 & 0.65 \\
\hline $1922-1939$ & \multicolumn{2}{|c|}{0.84} & 2.11 & 1.96 & 0.77 & 1.07 \\
\hline 1951-1974 & \multicolumn{2}{|c|}{0.66} & 5.30 & 5.76 & 1.42 & 4.27 \\
\hline 1975-2001 & \multicolumn{2}{|c|}{0.13} & 2.17 & 2.23 & 0.58 & 0.89 \\
\hline \multirow[t]{4}{*}{ 2002-2011 } & \multicolumn{2}{|c|}{0.63} & -0.37 & -0.37 & 0.09 & 0.28 \\
\hline & \multicolumn{5}{|c|}{ Labour productivity $^{\mathrm{b}}$} & \multirow{3}{*}{$\begin{array}{l}\text { Total } \\
\text { economy }\end{array}$} \\
\hline & \multirow[t]{2}{*}{ Agriculture } & \multirow[t]{2}{*}{ Industry } & \multicolumn{3}{|l|}{ Services } & \\
\hline & & & $\begin{array}{l}\text { Private } \\
\text { services }\end{array}$ & $\begin{array}{l}\text { Public } \\
\text { administration }\end{array}$ & Total services & \\
\hline $1862-1913$ & 0.03 & 0.07 & 0.55 & 0.41 & 0.52 & 0.21 \\
\hline 1922-1939 & 0.67 & 1.39 & 1.10 & 0.61 & 1.00 & 1.17 \\
\hline $1951-1974$ & 2.62 & 3.73 & 3.94 & 3.20 & 3.74 & 4.30 \\
\hline $1975-2001$ & 1.65 & 1.28 & - & - & 1.34 & 1.61 \\
\hline 2002-2011 & -0.69 & -0.73 & - & - & -0.50 & -0.47 \\
\hline
\end{tabular}

Average percentage changes over sub-periods-for value added, employment and labour productivity the third and fourth sub-periods refer, respectively, to 1951-1970 and 1971-2001

Source Authors' own calculations using Baffigi (2013) and Giordano and Zollino (2012) estimates

a Value added growth is computed by using the two different blocks of estimates 1861-1970 and 18612011—see text and (Baffigi, 2013, pp. 161-162)

$\mathrm{b}$ The level of labour productivity, of which the average annual growth rates have been computed, is calculated as the ratio of per capita value added to full-time equivalent employment by major sectors and for the aggregate economy

Republican Italy (1951-2011) had two clear breaks in 1974 and 2001, which are both highly significant. ${ }^{15}$

These dates, together with the ones that delimit the two World Wars, allow us to identify five key sub-periods (i.e., 1862-1913, 1922-1939, 1951-1974, 1975-2001 and 2002-2011) over which some interesting general features of Italy's economic history can be deduced. ${ }^{16}$ For this purpose, Table 1 presents average annual growth rates in the selected sub-periods for total population, aggregate per capita GDP and value added, as well as a number of key labour market variables (namely employment, real wages and labour productivity ${ }^{17}$ ).

\footnotetext{
15 The values of the supreme $F$ statistic for testing against a single-shift alternative of unknown timingi.e., model (1) with $m=1$-in the 1951-2011 and 1975-2011 growth rate sub-samples amounted in fact to 51 in 1974 and 12.2 in 2001, which exceed in both cases their respective $5 \%$ critical values of 8.6 and 8.7. See Andrews (1993) and Andrews and Ploberger (1994) for further details.

16 Such a periodization resembles that originally proposed by Fuà (1981), slightly modified for the postWorld War II period: pre-World War I period (1861-1913), interwar period (1922-1939), pre-oil shocks period (1951-1974), and post-oil shocks period (1975-2001).

17 Labour productivity is calculated as the ratio of per capita value added to full-time equivalent employment by major sectors and for the aggregate economy.
} 
From Unification to 1913, Italy's economic performance was generally quite modest: population grew an annual average rate of $0.7 \%$; the average growth rate of per capita GDP and value added was around 0.9 per annum, whereas employment and real wages grew on average respectively by 0.7 and 0.6 per year. The overall annual labour productivity growth rate was of $0.2 \%$; agriculture and industry displayed weak growth rates-less than $0.1 \%$ points, whereas labour productivity in the services sector grew at nearly $0.5 \%$ per year, with private services' productivity growth $(0.5 \%)$ outstripping that of government services $(0.4 \%)$.

During the interwar period, between 1922 and 1939, Italy's GDP per capita grew by $2.1 \%$ per year; the average growth rate of total value added per person was very similar ( $2 \%$ points per annum). Both the total population and full-time equivalent employment growth rates increased to $0.8 \%$ relative to the previous period, while real wages grew yearly at the tune of more than $1 \%$. All three sectors underwent a significant spurt in productivity, thus contributing to the $1.2 \%$ overall productivity growth rate. Whereas the labour productivity growth rate in agriculture increased to $0.7 \%$ per year, industry and services were even better achievers relative to the previous period: the former registering a conspicuous rate of $1.4 \%$ per year, the latter a rate of $1 \%$. Within the services sector, private services confirmed their leadership in productivity terms, growing at the $1.1 \%$ annual rate, whereas government services grew at the pace of $0.6 \%$ yearly.

A good part of Italy's secular convergence towards the more advanced countries occurred between 1951 and 1974. In a context of rapid opening-up to international competition coupled with protection and regulation of the domestic market, per capita GDP grew by an average of $5.3 \%$ points and total value added per capita increased annually by $5.8 \%$. The number of full-time equivalent workers grew faster than total population —on average, $1.4 \%$ per annum against 0.7 -while the yearly growth rate of real wages was about $4.3 \%$. Between 1951 and 1970, the increase in labour productivity growth rate reached a hitherto unprecedented overall average yearly rate of $4.3 \%$, with industry growing at an exceptional $3.7 \%$ annual rate. Agriculture too registered a strong yearly growth rate in these two decades $(2.6 \%$ points). In the services sector, which reached its highest ever yearly growth rate $(3.7 \%)$, personal services' productivity grew at its record $3.9 \%$, while the labour productivity growth rate in the government services sector was of $3.2 \%$, the highest ever registered in our selected sub-periods.

After the breakdown of the Bretton Woods cooperative monetary order and the first oil shock in the early 1970s, the pace of growth slowed down abruptly. Between 1975 and 2001 per capita GDP and value added still grew, on average, at the respectable annual rate of $2.2 \%$, but employment and aggregate labour productivity growth rates more than halved, down to 0.6 and $1.6 \%$ respectively. All three sectors were affected by a significant labour productivity slowdown: whereas growth in agricultural labour productivity fell to around $1.7 \%$ points per year, growth in industry and services dropped down even further to approximately $1.3 \%$. An abrupt deceleration in growth was also registered by real wages - only a modest annual average rate of $0.9 \%$, down from $4.3 \%$ of the previous period-while population growth is at around $0.1 \%$, the lowest ever. 
Table 2 Contributions to GDP growth by final demand components over sub-periods, 1862-2011

\begin{tabular}{|c|c|c|c|c|c|c|c|c|c|}
\hline & \multicolumn{7}{|c|}{ Expenditure components } & \multirow[t]{2}{*}{ GDP } & \multirow[t]{2}{*}{ Multiplier } \\
\hline & $\begin{array}{l}\text { Private } \\
\text { consumption }\end{array}$ & $\begin{array}{l}\text { Public } \\
\text { consumption }\end{array}$ & $\begin{array}{l}\text { Total fixed } \\
\text { investments }\end{array}$ & $\begin{array}{l}\text { Inventory } \\
\text { variation }\end{array}$ & Exports & Imports & $\begin{array}{l}\text { Net } \\
\text { exports }\end{array}$ & & \\
\hline \multicolumn{10}{|c|}{ Percentage values } \\
\hline $1862-1913$ & 0.56 & 0.08 & 0.25 & 0.01 & 0.18 & 0.16 & 0.02 & 0.92 & 1.80 \\
\hline 1922-1939 & 0.98 & 0.13 & 0.43 & 0.00 & 0.11 & -0.45 & 0.56 & 2.11 & 3.13 \\
\hline $1951-1974$ & 2.81 & 0.93 & 1.56 & 0.12 & 1.13 & 1.25 & -0.12 & 5.30 & 1.46 \\
\hline $1975-2001$ & 1.30 & 0.50 & 0.23 & -0.07 & 0.76 & 0.55 & 0.21 & 2.17 & 1.45 \\
\hline $2002-2011$ & 0.00 & 0.09 & -0.17 & -0.01 & 0.11 & 0.39 & -0.28 & -0.37 & -11.43 \\
\hline \multicolumn{10}{|c|}{ Percentage shares of GDP growth } \\
\hline $1862-1913$ & 60.68 & 8.70 & 27.65 & 0.68 & 19.28 & 16.99 & 2.29 & 100 & - \\
\hline 1922-1939 & 46.46 & 6.17 & 20.56 & 0.14 & 5.20 & -21.48 & 26.68 & 100 & - \\
\hline $1951-1974$ & 52.99 & 17.47 & 29.43 & 2.31 & 21.43 & 23.63 & -2.20 & 100 & - \\
\hline 1975-2001 & 59.80 & 23.13 & 10.80 & -3.21 & 35.02 & 25.54 & 9.48 & 100 & - \\
\hline $2002-2011^{b}$ & 0.58 & -24.37 & 45.40 & 1.40 & -29.78 & -106.77 & 76.99 & 100 & - \\
\hline
\end{tabular}

All values are averages over the periods

Source Authors' own calculations using Baffigi (2013) estimates

a The values of the autonomous spending's multiplier are derived using Eq. (5)

$\mathrm{b}$ A positive (negative) sign denotes a positive (negative) contribution to the decrease of GDP

Finally, the last period (2002-2011) was technically a lost decade, with both per capita GDP and value added displaying negative growth $(-0.4 \%)$. All sectors had negative labour productivity growth-between -0.5 and $-0.7 \%$ points per yearwhich explains the overall average yearly rate of $-0.5 \%$, whereas employment and real wages grew at the modest rates of 0.1 and $0.3 \%$, respectively. Total population is the only one that seems to have performed well in this period, showing a growth rate very similar to that registered for the years 1951-1974.

The availability of new estimates for the supply and uses accounts also enables us to identify the sources of growth for the identified periods. For this purpose, a simple accounting exercise breaking down changes in GDP according to the changes in different types of expenditures (consumption, investments, exports, etc.) is performed by using the well-known formula (e.g. Lequiller and Blades 2007, p. 28)

$$
g_{t}^{Y}=g_{t}^{C} \frac{C_{t-1}}{Y_{t-1}}+g_{t}^{G} \frac{G_{t-1}}{Y_{t-1}}+g_{t}^{I^{p}} \frac{I_{t-1}^{p}}{Y_{t-1}}+g_{t}^{I^{u}} \frac{I_{t-1}^{u}}{Y_{t-1}}+g_{t}^{X} \frac{X_{t-1}}{Y_{t-1}}-g_{t}^{M} \frac{M_{t-1}}{Y_{t-1}},
$$

where $C$ is private consumption, $G$ denotes the amount of total government spending, $I^{p}$ symbolizes the planned (total fixed) investments, $I^{u}$ is the unplanned inventory build-up, $X$ corresponds to exports and $M$ denotes imports. This equality, which is true by construction, facilitates separating and measuring the contribution of each component of demand to the change in GDP. The results have been summarised in Table 2 and Fig. 4, which adopt the same periodization as in Table 1. 


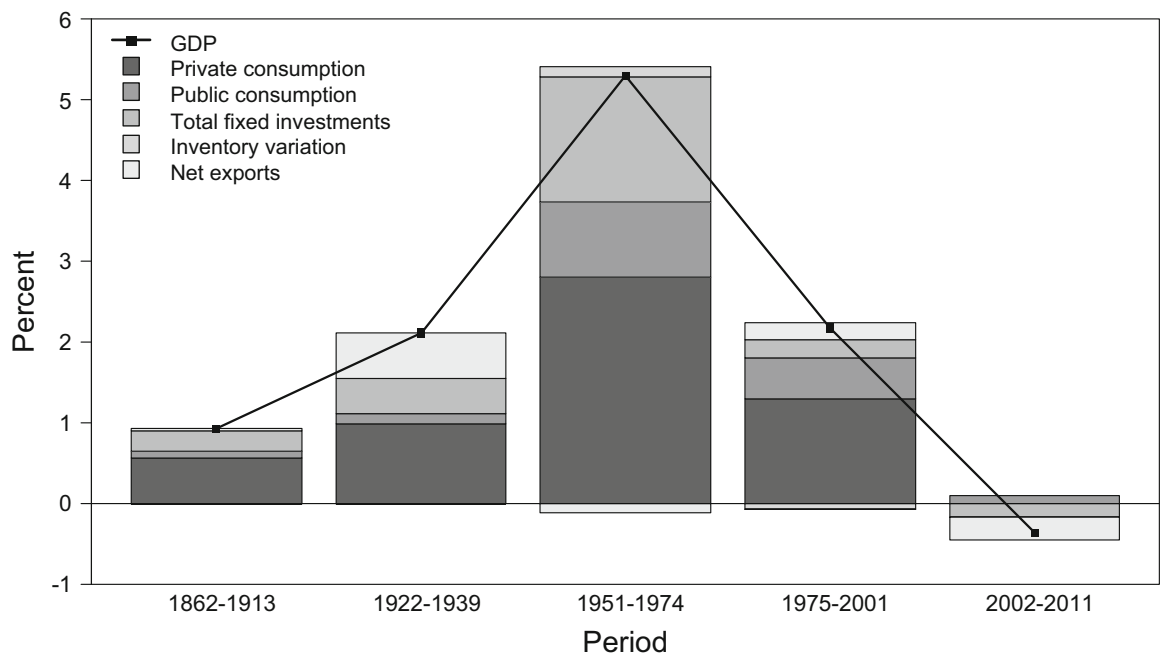

Fig. 4 Contributions to GDP growth by final demand components over sub-periods, 1862-2011. Source Authors' own calculations using Baffigi (2013) estimates

As noted above, over the full span 1862-1913 of post-Unification Italy the growth in GDP per capita was rather modest, averaging around $0.9 \%$ per annum. Our accounting exercise shows that it was private consumption, with a contribution of around $61 \%$ points, that drove growth during this period, more than total fixed investments $(27.7$ $\%)$, government consumption $(8.7 \%)$ and net exports $(2.3 \%) .{ }^{18}$

The period between the two World Wars (1922-1939) recorded an acceleration in GDP growth that was still propelled by the private sector: out of its average annual rate of $2.1,46.5 \%$ of the overall economic growth was contributed by private consumption and $20.6 \%$ by investment expenditure. Government spending, in turn, contributed only $6.2 \%$ to growth in respect to the previous period, whereas net exports swung to making a positive contribution of $26.7 \%$ as a result of the sharp falling off in import demand $(-21.5 \%)$ following the autarchic policies of the Fascist regime.

After World War II, between 1951 and 1974, over $50 \%$ of the exceptional GDP growth $(5.3 \%$ on average per year) was explained by private consumption, while total fixed investments contributed for approximately $29 \%$. This, with the help of public consumption that nearly tripled to $17.5 \%$ relative to the previous period, compensated the negative contribution of net exports $(-2.2 \%)$ due to the resurgence of the import content of GDP $(23.6 \%)$.

The years following the energy crisis and the breakdown of the Bretton Woods system of fixed exchange rates (1975-2001) were instead characterized by a significant slowdown in the pace of GDP growth, which dropped down to an average annual rate of $2.2 \%$. Private consumption was again the lead driver of growth, with a contribution of almost $60 \%$, while for the first time since Unification public spending's contribution

\footnotetext{
18 The contribution of net exports is calculated as the difference between the contribution of exports and that of imports.
} 
to GDP growth overtook that of private investment by more than a half-nearly $23 \%$ against less than $11 \%$, respectively. Net exports, for their part, contributed positively to growth with over $9 \%$, on account of the large positive contribution of exports (35\%).

Finally, the negative growth recorded by GDP per capita in the most recent years (2002-2011) was mainly driven by net exports (77\%), followed by total fixed investments $(45.4 \%)$ and private consumption $(0.6 \%)$. Government consumption was the only component of aggregate demand that sustained a positive trend during this period, with a contribution of nearly $24 \%$ points. However, this share was inadequate to cancel out negative growth in other components of final demand, thus leaving GDP with a $0.4 \%$ drop in average annual growth.

The analysis conducted above can also be expanded to assess how the autonomous spending - made up of government purchases, investments and exports-impacted on the growth rate of per capita GDP via its multiplier effect. For this purpose, we rewrite Eq. (2) as

$$
g_{t}^{Y}=\frac{\Delta C_{t}}{Y_{t-1}}+g_{t}^{C} \frac{G_{t-1}}{Y_{t-1}}+g_{t}^{I^{p}} \frac{I_{t-1}^{p}}{Y_{t-1}}+g_{t}^{X} \frac{X_{t-1}}{Y_{t-1}}-\frac{\Delta M_{t}}{Y_{t-1}},
$$

where we assume for the sake of simplicity (and without loss of generality) that there are no inventories. Dividing and multiplying the first and last term on the right-hand side by $\Delta Y_{t}$ and reorganizing, we obtain

$$
\begin{aligned}
g_{t}^{Y} & =\frac{\Delta C_{t}}{\Delta Y_{t}} \frac{\Delta Y_{t}}{Y_{t-1}}+g_{t}^{C} \frac{G_{t-1}}{Y_{t-1}}+g_{t}^{I^{p}} \frac{I_{t-1}^{p}}{Y_{t-1}}+g_{t}^{X} \frac{X_{t-1}}{Y_{t-1}}-\frac{\Delta M_{t}}{\Delta Y_{t}} \frac{\Delta Y_{t}}{Y_{t-1}} \\
& =c g_{t}^{Y}+g_{t}^{C} \frac{G_{t-1}}{Y_{t-1}}+g_{t}^{I^{p}} \frac{I_{t-1}^{p}}{Y_{t-1}}+g_{t}^{X} \frac{X_{t-1}}{Y_{t-1}}-m g_{t}^{Y},
\end{aligned}
$$

where $c$ denotes the marginal propensity to consume and $m$ is the marginal propensity to import. Finally, further simple rearrangements lead to

$$
g_{t}^{Y}=\frac{1}{1-c+m}\left(g_{t}^{C} \frac{G_{t-1}}{Y_{t-1}}+g_{t}^{I^{p}} \frac{I_{t-1}^{p}}{Y_{t-1}}+g_{t}^{X} \frac{X_{t-1}}{Y_{t-1}}\right),
$$

where the pre-multiplicative factor on the right-hand side is the autonomous spending's multiplier. ${ }^{19}$ The value of the latter, derived from application of the formula above, is provided in the last column of Table 2 for the different periods of unified Italy's history.

During the period before World War I, autonomous expenditure is found to be substantially expansionary, with a multiplier averaging around 1.8. Its impact on output growth in the interwar years between 1922 and 1939 appears even more significant

\footnotetext{
19 We assume here that the marginal propensities to consume and import are fixed over time. This allows us to calculate the multiplier of Eq. (5) as a "residual"-i.e., after the average GDP growth rate and autonomous spending over different time periods have been calculated. Allowing the marginal propensities to be time-varying - that is, taking the mean of the multiplier itself over time-does not qualitatively affect our results.
} 
Table 3 Contributions to value added growth by sectors over sub-periods, 1862-2011

\begin{tabular}{|c|c|c|c|c|c|c|}
\hline & \multicolumn{5}{|c|}{ Sectoral value added } & \multirow[t]{3}{*}{ Total value addec } \\
\hline & \multirow[t]{2}{*}{ Agriculture } & \multirow[t]{2}{*}{ Industry } & \multicolumn{2}{|l|}{ Services $^{\mathrm{a}}$} & \multirow[t]{2}{*}{ Total services } & \\
\hline & & & $\begin{array}{l}\text { Private } \\
\text { services }\end{array}$ & $\begin{array}{l}\text { Public } \\
\text { administration }\end{array}$ & & \\
\hline \multicolumn{7}{|c|}{ Percentage values } \\
\hline $1862-1913$ & 0.17 & 0.23 & 0.41 & 0.09 & 0.50 & 0.89 \\
\hline 1922-1939 & -0.04 & 1.02 & 0.66 & 0.31 & 0.97 & 1.96 \\
\hline $1951-1970$ & -0.06 & 2.59 & 2.58 & 0.66 & 3.24 & 5.76 \\
\hline 1971-2001 & -0.07 & 0.41 & - & - & 1.88 & 2.23 \\
\hline 2002-2011 & -0.07 & -0.37 & - & - & 0.07 & -0.37 \\
\hline \multicolumn{7}{|c|}{ Percentage shares of total value added growth } \\
\hline $1862-1913$ & 19.14 & 25.21 & 46.06 & 9.58 & 55.65 & 100 \\
\hline 1922-1939 & -1.94 & 52.23 & 33.74 & 15.97 & 49.71 & 100 \\
\hline $1951-1970$ & -1.06 & 44.86 & 44.70 & 11.50 & 56.20 & 100 \\
\hline $1971-2001$ & -3.06 & 18.51 & - & - & 84.55 & 100 \\
\hline $2002-2011^{b}$ & 18.63 & 100.10 & - & - & -18.73 & 100 \\
\hline
\end{tabular}

All values are averages over the periods

Source Authors' own calculations using Baffigi (2013) estimates

a Disaggregation levels for service sector value added are only available up to 1970; from 1971 onwards, the block of 1861-2011 estimates is used-see text and Baffigi (2013, pp. 161-162)

${ }^{\mathrm{b}}$ A positive (negative) sign denotes a positive (negative) contribution to the decrease of total value added

and sizeable, with a mean multiplier as large as 3.1, while spending effects are found to be smaller in the following two periods-i.e., 1951-1974 and 1975-2001—where the value of the multiplier is lower relative to the previous period (ranging, on average, between 1.4 and 1.5). Finally, in the last decade (2002-2011) the autonomous spending's multiplier reached a considerable negative value of about -11.4 ; however, if one breaks the period down further (2002-2009) in order to net out the effect of the recent negative downturn, the multiplier turns back to a positive value of around 1 .

The same accounting exercise performed to compile demand-side contributions to GDP growth has also been repeated for assessing the contributions to total value added growth by sector, where each sector's contribution is equal to its own value added growth rate multiplied by its share in total value added of the previous year. The corresponding results are shown in Table 3 and Fig. $5 .^{20}$

Based on our estimates, we find that Italy's production structure underwent many important changes during different periods since 1861 .

In the liberal period (1862-1913) services were the main growth contributors. Overall services contributed about $56 \%$ to aggregate value added growth, followed by industry (around $25 \%$ ) and agriculture (slightly more than $19 \%$ ). Among services,

\footnotetext{
20 The periodization here differs slightly to that presented in Tables 1, 2 and Fig. 4, as two different datasets are used for value added that respectively cover the years 1861-1970 and 1861-2011. See Sect. 2, footnote 7, and Baffigi (2013, pp. 161-162) for further details.
} 


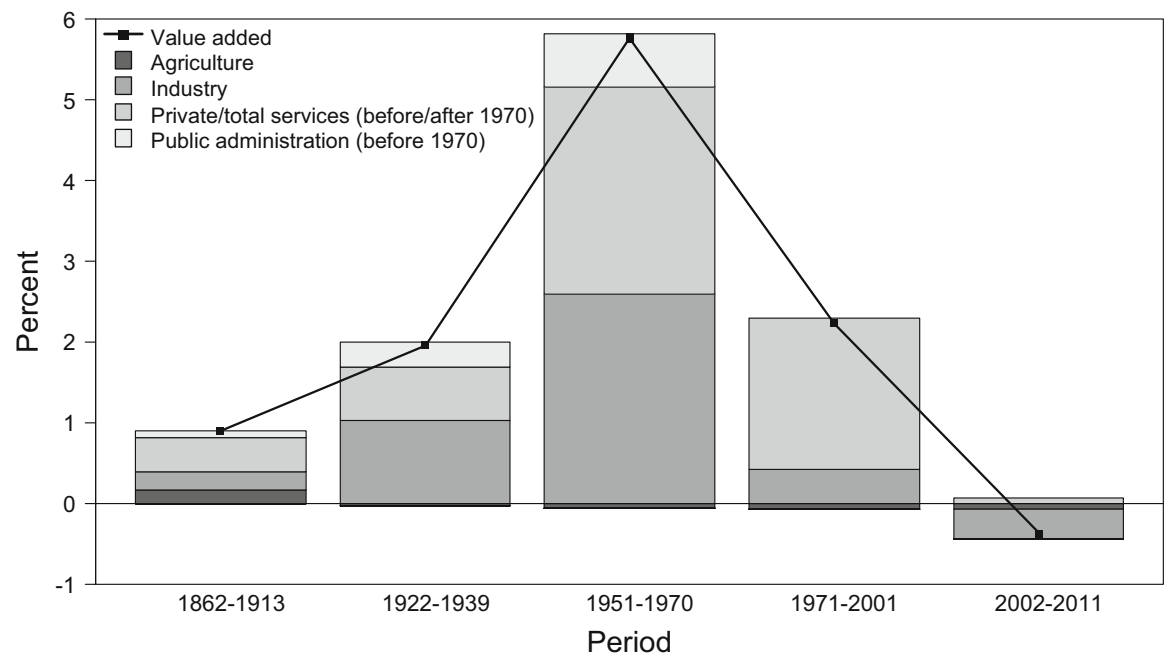

Fig. 5 Contributions to value added growth by sectors over sub-periods, 1862-2011. Source Authors' own calculations using Baffigi (2013) estimates

the largest contributors were private services, roughly accounting for a total $46 \%$ of the aggregate value added change over the whole period, while government services showed only a minor contribution (less than $10 \%$ ).

During the Fascist period (1922-1939) industry was by far the main contributing sector, accounting for approximately $52 \%$ of total value added growth. Services sector's contribution was still relatively high, at around $50 \%$, while agriculture recorded a negative contribution (almost $-2 \%$ ). At a lower level of sectoral breakdown, the contribution by private services has become markedly less relative to the previous period (about $34 \%$ ), in contrast to government services sector that accounts now for a larger share of overall value added growth than previously found (around $16 \%$ ).

The impressive growth of the years following World War II (1951-1970), reaching a hitherto unprecedented overall average yearly rate of around $5.8 \%$, was heavily concentrated in the services sector-which accounted for more than half (approximately $56 \%$ ) of total value added growth — and industry — which provided a positive contribution to overall growth as large as about $45 \%$ points. The agricultural sector, instead, still contributed negatively (around $-1 \%$ ), whereas in the services sector we again find a considerable contribution by private services (slightly less than $45 \%$ ) and a relatively smaller one by the state public administration (nearly $12 \%$ ).

In the 1971-2001 period, growth of total value added more than halved, dropping down to an average yearly rate of around $2.2 \%$. Industry also lost momentum, but still explained almost $19 \%$ of the overall growth. By contrast, the highest ever contribution to value added growth (about $85 \%$ ) came from the services sector, which for much of the period under consideration was by far the largest sector. Agriculture, for its part, continued to negatively affect growth with a contribution of nearly $-3 \%$ points, which is considerably more sizeable than in the previous periods. 
Finally, in the last period (2002-2011) total value added registered a negative average annual growth rate of almost $-0.4 \%$, which can be explained by the unfavourable performance of the industrial sector, but also agriculture. A quick glance at the second column of Table 3 (or the last bar in Fig. 5) reveals indeed that nearly all of the decrease in overall growth from 2002 to 2011 may be explained by the decline in industry's value added, although the negative role exerted by agriculture over the whole period still remains quite large (accounting for around $19 \%$, which makes a substantially higher contribution when compared to its relative performance in previous years). Total services, which contributed positively to almost one quarter (19\%) of overall growth, only partly offset the negative performance of the former sectors.

To conclude the section, we can quantify the relative importance of internal labour productivity growth in Italy's three sectors (agriculture, industry and services) by estimating sectoral contributions to aggregate productivity growth. For this purpose, we rely upon the traditional decomposition formula (e.g. Dumagan 2013, p. 162)

$$
\begin{aligned}
g_{t}^{Z} & =\sum_{i} \frac{V A_{i, t-1}}{V A_{t-1}} g_{i, t}^{Z}+\sum_{i} \frac{Z_{i, t-1}}{Z_{t-1}} \Delta l_{i, t}+\sum_{i} \frac{Z_{i, t-1}}{Z_{t-1}} \Delta l_{i, t} g_{i, t}^{Z}, \\
i & =1, \ldots, N, \quad t=1, \ldots, T,
\end{aligned}
$$

where aggregate labour productivity is $Z_{t}=V A_{t} / L_{t}$ and sectoral productivity is $Z_{i, t}=V A_{i, t} / L_{i, t}$, with $L_{t}$ and $L_{i, t}$ representing labour inputs used in the aggregate economy and in sector $i$ such that $L_{t}=\sum_{i} L_{i, t}$. In this case, aggregate labour productivity is equal to the weighted sum of sectoral labour productivity across all $i$ 's, i.e. $Z_{t}=V A_{t} / L_{t}=\sum_{i} V A_{i, t} / L_{t}=\sum_{i} Z_{i, t} L_{i, t} / L_{t}=\sum_{i} Z_{i, t} l_{i, t}$, where the weights $l_{i, t}=L_{i, t} / L_{t}$ are each sector's labour input shares.

According to this formula, aggregate labour productivity growth $\left(g_{t}^{Z}=Z_{t} / Z_{t-1}-\right.$ 1) can be broken down into three effects. ${ }^{21}$ The first term on the right-hand side of Eq. (6) represents the "within-sector effect" (henceforth WSE). The WSE measures the contribution to aggregate productivity growth due solely to productivity increases experienced by individual sectors: if sectoral labour input shares remain unchanged over time $\left(\Delta l_{i, t}=l_{i, t}-l_{i, t-1}=0\right)$, the second and third terms of Eq. (6) equal zero and the contribution of each sector collapses to the first term, which is the sum of sectoral labour productivity growth $\left(g_{i, t}^{Z}=Z_{i, t} / Z_{i, t-1}-1\right)$ weighted by each sector's share in aggregate value added $\left(V A_{i, t-1} / V A_{t-1}\right)$.

The other two terms of the equation represent two different reallocation effects. The second term captures the "reallocation level effect" (henceforth RLE). As Denison (1962) realized, aggregate labour productivity can increase even when sectoral labour productivity remains constant, as long as employment moves from low-productivity to high-productivity sectors. In the decomposition given by Eq. (6), the RLE is positive for a sector when $\Delta l_{i, t}>0$; the ratio between each sector's labour productivity level

\footnotetext{
21 Dumagan (2013,p. 162) denotes these three effects respectively as the "within-sector productivity growth effect", the "static structural reallocation effect" and the "dynamic structural reallocation effect". See also Nordhaus (2002) and Tang and Wang (2004) for slightly different labels. Following de Avillez (2012), in the text we shall refer to these effects as the "within-sector effect", the "reallocation level effect" and "reallocation growth effect", respectively.
} 
and the aggregate labour productivity level scales the magnitude of the sectoral RLE either increasing it (when $Z_{i, t} / Z_{t}>1$ ) or decreasing it (when $Z_{i, t} / Z_{t}<1$ ).

Finally, the third term is the "reallocation growth effect" (henceforth RGE). The RGE captures a phenomenon based on the findings of Baumol (1967) and Baumol et al. (1985), that is the tendency of labour to move towards sectors with relatively small increases in labour productivity. In the decomposition Eq. (6), the RGE is negative for any given sector if either the change in labour productivity $\left(g_{i, t}^{Z}\right)$ or the variation in employment share $\left(\Delta l_{i, t}\right)$ is negative. Conversely, it is positive for a sector if employment increases (decreases) in that sector and productivity is also increasing (decreasing) in the same sector. The magnitude of the sectoral RGE depends not only on $\Delta l_{i, t}$ and $g_{i, t}^{Z}$ but also on the ratio between the sector's labour productivity level and the aggregate labour productivity level $\left(Z_{i, t} / Z_{t}\right){ }^{22}$

If the three effects are aggregated for each sector, we can analyze each sector's contribution to aggregate productivity growth; hence, the decomposition (6) can be rewritten as

$$
\begin{aligned}
g_{t}^{Z} & =\sum_{i}\left[\frac{V A_{i, t-1}}{V A_{t-1}} g_{i, t}^{Z}+\frac{Z_{i, t-1}}{Z_{t-1}} \Delta l_{i, t}+\frac{Z_{i, t-1}}{Z_{t-1}} \Delta l_{i, t} g_{i, t}^{Z}\right], \\
i & =1, \ldots, N, \quad t=1, \ldots, T .
\end{aligned}
$$

The results of our decomposition analysis for Italy over key sub-periods are given in Table 4 (as per cent contributions to aggregate labour productivity growth) and Table 5 (as percentages of total growth). ${ }^{23}$

The contributions of the different effects and sectors to aggregate labour productivity growth are also shown, respectively, in Figs. 6 and 7.

The overriding conclusion derived from the tables and figures above is that the aggregate productivity performance over the 150 years of Italian national life was mainly fuelled by within-sector productivity growth. This is most clear in the 19511970 and 1971-2001 periods, where the WSE accounted for around $80 \%$ of total labour productivity growth. However, this effect played an important role (around 76 $\%$ of total growth) also during the first fifty years of Italy's unified history (1862-1913), whereas in the most recent period (2002-2001) the WSE contribution was negative and higher than actual labour productivity change (nearly $121 \%$ of the total), thus arising by far as the main responsible for the negative growth recorded in these years ( $-0.5 \%$ points).

Reallocation effects were also important. In the 1862-1913 and 1922-1939 periods, labour was generally moving to sectors with high productivity and out of sectors with low productivity - the RLE provided in fact positive contributions as large as 50 $\%$ of aggregate productivity growth. The reallocation of workers from less to more productive sectors was also significant in the following two periods (1951-1970 and

\footnotetext{
22 One could use mean weights to eliminate the RGE term, as in Syrquin (1984), but we retain it because this term can be given an interesting economic interpretation. As sectors differ not only in terms of productivity levels, but also in terms of productivity growth rates, resource reallocation has both static and dynamic effects and a distinction between the two is useful.

23 The tables adopt the same periodization as in Table 3 and Fig. 5 (see footnote 17).
} 
Table 4 Sectoral contributions to labour productivity growth over sub-periods, 1862-2011

\begin{tabular}{|c|c|c|c|c|c|}
\hline & $1862-1913$ & 1922-1939 & $1951-1970$ & 1971-2001 & 2002-2011 \\
\hline \multicolumn{6}{|l|}{ Agriculture } \\
\hline WSE & -0.02 & 0.08 & 0.35 & 0.09 & -0.02 \\
\hline RLE & -0.11 & -0.35 & -0.65 & -0.18 & -0.05 \\
\hline RGE & 0.00 & -0.03 & -0.02 & 0.00 & 0.00 \\
\hline Total contribution & -0.13 & -0.30 & -0.32 & -0.10 & -0.07 \\
\hline \multicolumn{6}{|l|}{ Industry } \\
\hline WSE & 0.01 & 0.29 & 1.40 & 0.44 & -0.20 \\
\hline RLE & 0.12 & 0.58 & 0.62 & -0.33 & -0.21 \\
\hline RGE & -0.05 & -0.08 & 0.02 & -0.01 & 0.00 \\
\hline Total contribution & 0.07 & 0.80 & 2.03 & 0.10 & -0.41 \\
\hline \multicolumn{6}{|l|}{ Services $^{\mathrm{a}}$} \\
\hline \multicolumn{6}{|l|}{ Private services } \\
\hline WSE & 0.16 & 0.34 & 1.40 & - & - \\
\hline RLE & 0.05 & 0.10 & 0.63 & - & - \\
\hline RGE & 0.00 & -0.02 & 0.02 & - & - \\
\hline Total contribution & 0.22 & 0.42 & 2.05 & - & - \\
\hline \multicolumn{6}{|l|}{ Public administration } \\
\hline WSE & 0.00 & 0.00 & 0.28 & - & - \\
\hline RLE & 0.05 & 0.26 & 0.24 & - & - \\
\hline RGE & 0.00 & 0.00 & 0.01 & - & - \\
\hline Total contribution & 0.05 & 0.26 & 0.53 & - & - \\
\hline \multicolumn{6}{|l|}{ Total services } \\
\hline WSE & 0.18 & 0.36 & 1.67 & 0.78 & -0.35 \\
\hline RLE & 0.09 & 0.33 & 0.88 & 0.82 & 0.36 \\
\hline RGE & 0.00 & -0.02 & 0.03 & 0.01 & 0.00 \\
\hline Total contribution & 0.27 & 0.67 & 2.58 & 1.61 & 0.01 \\
\hline \multicolumn{6}{|c|}{ Aggregate labour productivity } \\
\hline WSE & 0.16 & 0.73 & 3.42 & 1.31 & -0.57 \\
\hline RLE & 0.11 & 0.56 & 0.85 & 0.30 & 0.10 \\
\hline RGE & -0.06 & -0.12 & 0.03 & 0.00 & 0.00 \\
\hline Total growth & 0.21 & 1.17 & 4.30 & 1.61 & -0.47 \\
\hline
\end{tabular}

All values, expressed in percentage points, are averages over the periods; numbers may not add up to due to rounding

Source Authors' own calculations using Baffigi (2013) estimate

$W S E$ within-sector effect, $R L E$ reallocation level effect, $R G E$ reallocation growth effect

a Disaggregation levels for service sector value added are only available up to 1970; from 1971 onwards, the block of 1861-2011 estimates is used-see text and Baffigi (2013, pp. 161-162)

1971-2001), where the RLE contributed approximately $20 \%$ of total growth. Labour shifts contributed positively ( $0.1 \%$ points) even in the last period considered (20022011), hence avoiding a more unfavourable decrease of aggregate labour productivity growth. 
Table 5 Sectoral contributions to labour productivity growth over sub-periods, 1862-2011: percentage shares of aggregate labour productivity growth

\begin{tabular}{|c|c|c|c|c|c|}
\hline & $1862-1913$ & 1922-1939 & $1951-1970$ & 1971-2001 & $2002-2011^{\mathrm{a}}$ \\
\hline \multicolumn{6}{|l|}{ Agriculture } \\
\hline WSE & -9.72 & 6.81 & 8.21 & 5.53 & 3.96 \\
\hline RLE & -50.13 & -30.04 & -15.12 & -11.48 & 11.45 \\
\hline RGE & -0.04 & -2.36 & -0.43 & -0.25 & 0.08 \\
\hline Total contribution & -59.88 & -25.59 & -7.34 & -6.20 & 15.49 \\
\hline \multicolumn{6}{|l|}{ Industry } \\
\hline WSE & 2.46 & 24.68 & 32.53 & 27.23 & 42.95 \\
\hline RLE & 56.64 & 49.96 & 14.44 & -20.70 & 44.20 \\
\hline RGE & -25.81 & -6.55 & 0.38 & -0.48 & -0.94 \\
\hline Total contribution & 33.29 & 68.08 & 47.35 & 6.06 & 86.21 \\
\hline \multicolumn{6}{|l|}{ Services $^{b}$} \\
\hline \multicolumn{6}{|l|}{ Private services } \\
\hline WSE & 76.99 & 28.85 & 32.63 & - & - \\
\hline RLE & 25.99 & 8.63 & 14.70 & - & - \\
\hline RGE & -0.20 & -2.00 & 0.41 & - & - \\
\hline Total contribution & 102.78 & 35.49 & 47.75 & - & - \\
\hline \multicolumn{6}{|l|}{ Public administration } \\
\hline WSE & -0.56 & -0.06 & 6.58 & - & - \\
\hline RLE & 24.70 & 22.37 & 5.47 & - & - \\
\hline RGE & -0.32 & -0.28 & 0.20 & - & - \\
\hline Total contribution & 23.81 & 22.02 & 12.25 & - & - \\
\hline \multicolumn{6}{|l|}{ Total services } \\
\hline WSE & 83.19 & 31.02 & 38.84 & 48.73 & 74.13 \\
\hline RLE & 43.56 & 28.04 & 20.50 & 50.94 & -76.57 \\
\hline RGE & -0.16 & -1.55 & 0.66 & 0.48 & 0.74 \\
\hline Total contribution & 126.59 & 57.51 & 60.00 & 100.14 & -1.71 \\
\hline \multicolumn{6}{|c|}{ Aggregate labour productivity } \\
\hline WSE & 75.93 & 62.50 & 79.58 & 81.49 & 121.04 \\
\hline RLE & 50.08 & 47.96 & 19.81 & 18.75 & -20.92 \\
\hline RGE & -26.01 & -10.47 & 0.61 & -0.24 & -0.12 \\
\hline Total growth & 100 & 100 & 100 & 100 & 100 \\
\hline
\end{tabular}

All values are averages over the periods; numbers may not add up due to rounding

Source Authors' own calculations using Baffigi (2013) estimates

$W S E$ within-sector effect, $R L E$ reallocation level effect, $R G E$ reallocation growth effect

a A positive (negative) sign denotes a positive (negative) contribution to the decrease of aggregate labour productivity

b Disaggregation levels for service sector value added are only available up to 1970; from 1971 onwards, the block of 1861-2011 estimates is used-see text and Baffigi (2013, pp. 161-162)

Quite importantly, labour was also moving out of sectors with increasing productivity and into sectors with relatively small productivity increases. This shift is reflected in the negative RGE term, which in the first two periods (1862-1913 and 1922-1939) 


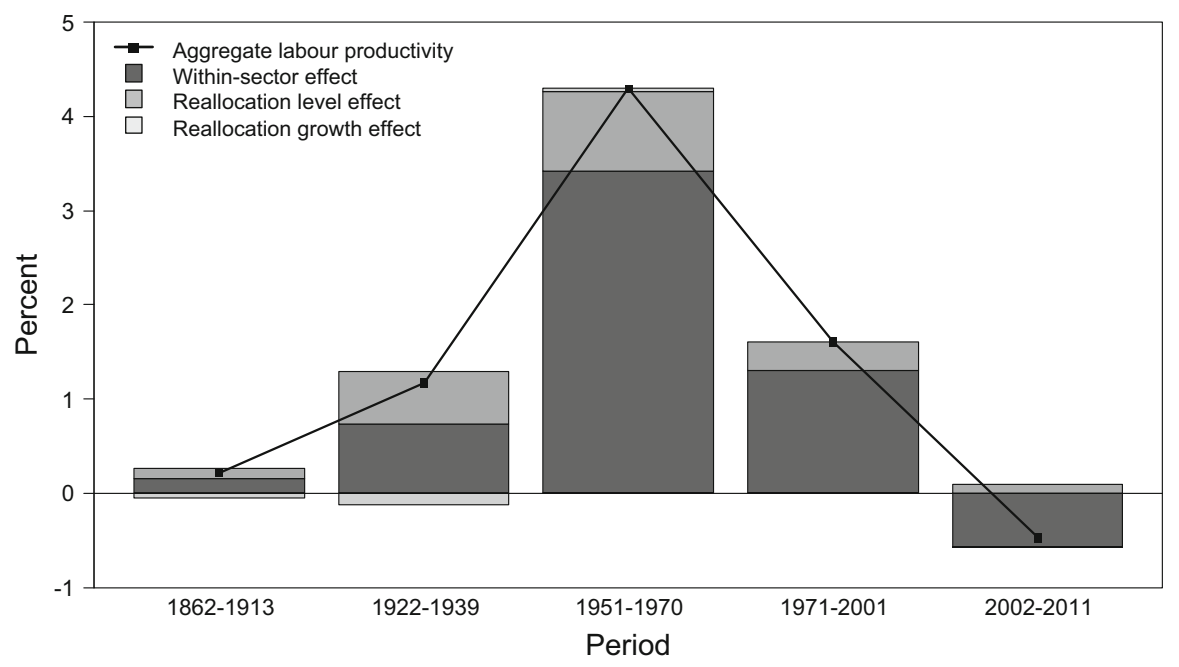

Fig. 6 Decomposition of aggregate labour productivity growth over sub-periods, 1862-2011. Source Authors' own calculations using Baffigi (2013) estimates

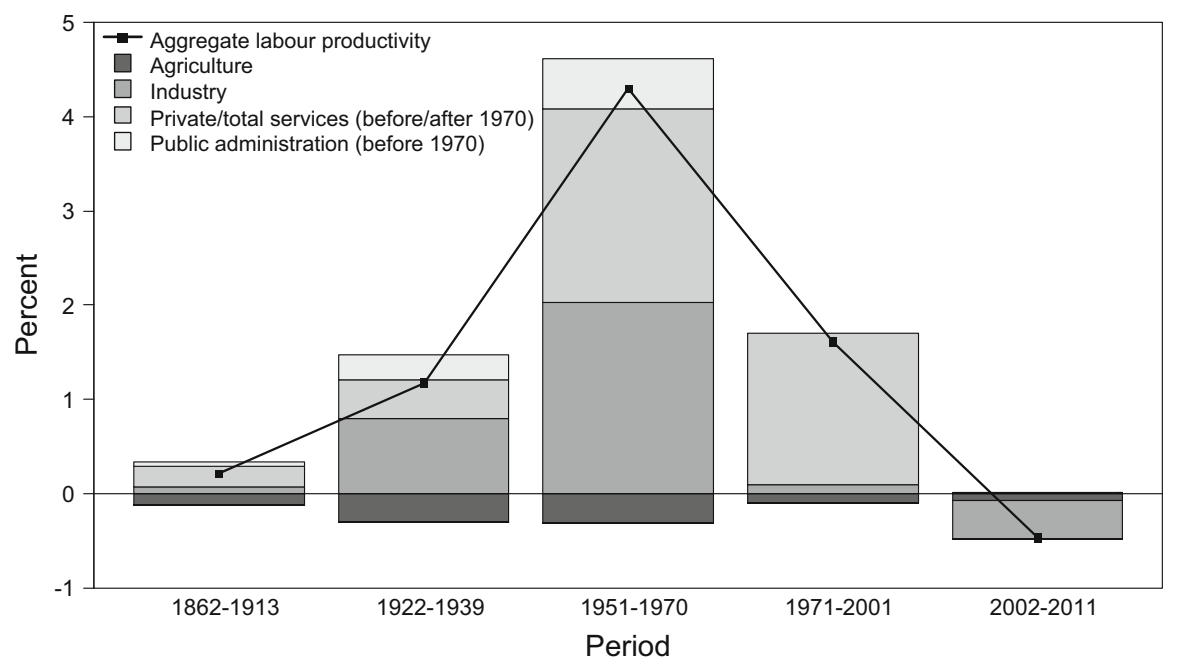

Fig. 7 Sectoral contributions to aggregate labour productivity growth over sub-periods, 1862-2011. Source Authors' own calculations using Baffigi (2013) estimates

reduced aggregate labour productivity growth by around $0.1 \%$ points (between -10 and $-26 \%$ of the total). Conversely, over the post-World war II period as a whole (1951-2011) the total reallocation effect-the sum of the RLE and the RGE-was very close to the RLE because of small reallocation growth effects.

In terms of total sectoral contributions, services as a whole made the largest contribution to aggregate labour productivity growth in 3 out of 5 of the periods considered (i.e, 1862-1913, 1951-1970 and 1971-2001), with private services in the 
lead-government services recorded only a minor contribution. Industry's contribution, in turn, was less than one third of that in services in the 1862-1913 and 1971-2001 periods, but was much closer to services in the 1951-1970 period ( $2 \%$ points, or 47 percent of total growth, for industry compared to $2.6 \%$ points, or $60 \%$ of total growth, for services). The industry sector was instead the main engine of aggregate productivity growth in the years from 1922 to 1939 ( $0.8 \%$ points or $68 \%$ of total growth). As for agriculture, it contributed negatively throughout; in particular, there were notable negative contributions in the first two periods 1862-1913 and 1922-1939 (respectively, -60 and $-26 \%$ of total growth). Finally, in the most recent years (2002-2011) industry ( $-0.4 \%$ points) and, to a lesser extent, agriculture (around $-0.1 \%$ points) were mainly responsible for the negative labour productivity growth $(-0.5 \%$ points); the services' sector, which made only a modest positive contribution, did not succeed in offsetting the largest negative contributions coming from the other two sectors.

Note, however, that the individual components of sectoral contributions to aggregate labour productivity growth were quite different in the long run. During the years $1862-$ 1913 and 1922-1939, services contributed mainly through within-sector productivity growth, whereas the industry sector experienced important reallocation effects by absorbing more workers from agriculture-where negative reallocation effects more than offset this sector's labour productivity growth, especially in the 1922-1939 period. After World War II, between 1951 and 1970, Italy's exceptional productivity growth was instead characterized by large productivity growth in both the industry and services sectors-although the country's productivity also grew slightly through a labour shift from agriculture to industry and services, which were sectors with both aboveaverage and increasing productivity. In the 1971-2001 period, services increased their own productivity and absorbed more workers from both the agricultural and industry sectors, where significant negative reallocation effects occurred; however, while the magnitude of these labour shifts in agriculture was more than enough to offset the within-sector productivity growth, this was not the case with industry, where the WSE contribution was higher than the actual joint reallocation effect (RLE + RGE). Finally, the negative Italian productivity performance of the most recent period (20022011) was characterized by negative within-sector effects in all sectors and shifts of employment away from agriculture to industry and services. Within services, the total reallocation effect was more than enough to offset the negative productivity performance of this sector, causing it to have a slightly positive contribution to aggregate labour productivity growth.

\section{The Italian Business Cycle Over Time}

Business cycle dating, through detection of business cycle turning points, and analysis of individual business cycle phases do represent fundamental issues in the traditional approach to business cycle analysis proposed by Burns and Mitchell (1946) and identified with NBER's research methodology. Differently, recent theoretical and empirical business cycle researches have focussed on the statistical properties of the deviations from trend in GDP and macroeconomic variables searching for regularities in terms of persistence, volatility and co-movements-the so-called "styilized facts" of busi- 
ness cycles_-as measured by autocorrelation, standard deviation and cross-correlation, respectively.

Such different analytical tools reflect differences in the business cycle definition between the two approaches. According to the modern approach to business cycles, economic fluctuations are characterized by "co-movements among different aggregative time series", which are common to all decentralized market economies with no restriction "to particular countries or time period", and therefore they are all alike (Lucas 1977, p. 217). ${ }^{24}$ This notion replaces NBER's view that the business cycle "consists of expansions occurring at about the same time in many economic activities, followed by similarly general recessions, contractions, and revivals which merge into the expansion phase of the next cycle" (Burns and Mitchell 1946).

Although the two approaches differ as to the characterization of business cycles and the object of analysis, they share the view about the underlying cyclical component as represented by a data generation process with a duration of two to eight years. Indeed, both analyses require to isolate business cycle fluctuations at the typical business cycle frequencies, that is at frequencies between 1.5 (2) and 8 years (Stock and Watson 1999). Therefore, since classical and modern approaches to business cycle analysis provide complementary informative content about business cycle fluctuations, the objective of this section is to compare across different periods of unified Italy's history the key features of business cycle fluctuations, i.e. persistence, volatility and asymmetry, and investigate the co-movements of output with several selected macroeconomic time series.

\subsection{Business Cycles Features}

Preliminary identification of turning points is needed in order to document the main characteristics of business cycle fluctuations. The chronology of business cycles provides a collection of dates at which the business cycle component reaches a peak or a trough, and then defines periods of contractions and expansions in economic activity with declining and increasing growth rates, respectively. Following the definition of the modern approach to business cycle analysis, we establish a business cycle chronology based on the "growth cycle" approach, which delineates periods of cyclical upswings and downswings around an underlying trend. The methodology used to identify peaks and troughs in the "growth rate" cycle approach differ from that used by classical analysis, which is based upon the series expressed in levels, in that business cycles and turning points are measured and identified in the deviation-from-trend series. In particular, as in Clementi et al. (2012), we use a procedure proposed by Artis et al. (2004) for quarterly data. ${ }^{25}$ First, local maxima (peaks) and minima (troughs) are selected as

\footnotetext{
24 The hypothesis that business cycles are "all alike" is a corollary of the assumption that all agents of the same type are identical. In this way the representative agent can be used as an analytical tool for microfounded macroeconomic analysis where the aggregate outcome can be obtained by means of a simple summation of the choices made by each optimizing agent.

25 The procedure proposed by Artis et al. (2004) is an extension to "growth cycles" of the original Bry and Boschan (1971) procedure for programmed determination of "classical cycles" turning point dates.
} 


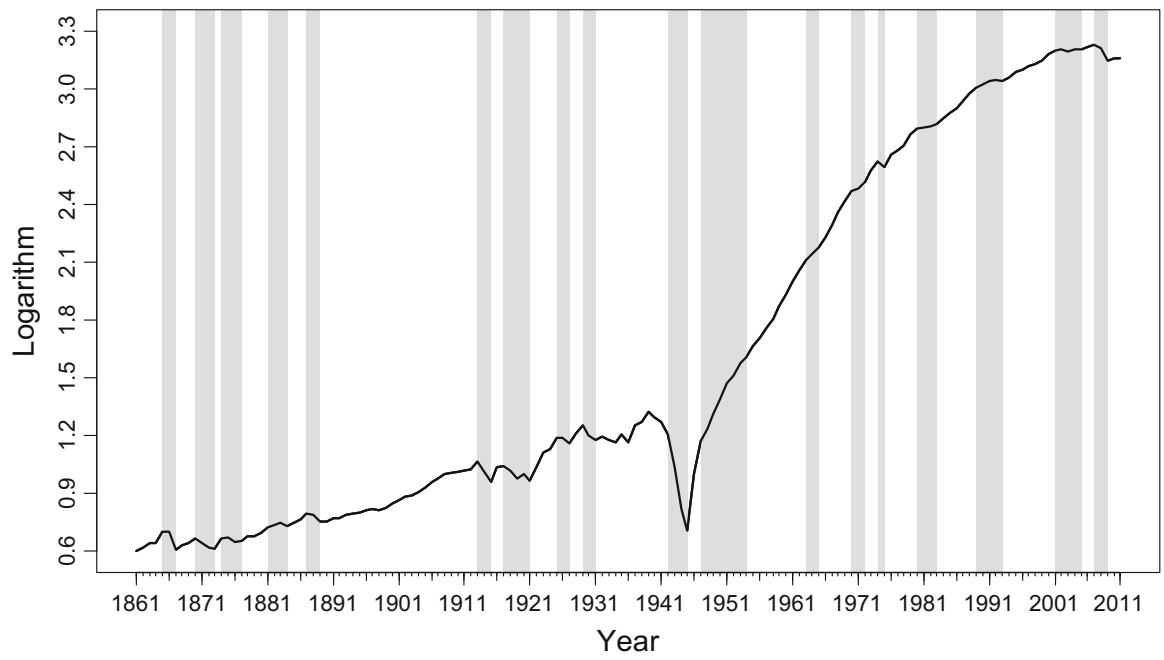

Fig. 8 Phases of contraction in Italy's economic activity, 1861-2011. Source Authors' own calculations using Baffigi (2013) estimates

$$
\left\{\begin{array}{ll}
\mathrm{P}_{t}=1, & \text { if }\left(c_{t}>0\right) \cap\left(c_{t}>c_{t-1}\right) \cap\left(c_{t}>c_{t+1}\right) \\
\mathrm{T}_{t}=1, & \text { if }\left(c_{t}<0\right) \cap\left(c_{t}<c_{t-1}\right) \cap\left(c_{t}<c_{t+1}\right)
\end{array}, \quad t=2, \ldots, T-1,\right.
$$

where $\mathrm{P}_{t}$ and $\mathrm{T}_{t}$ denotes candidate turning points (peaks and troughs, respectively) and $c_{t}$ is the cyclical component. In addition, for candidate peaks and troughs to become turning points the amplitude of a phase is required to be at least as large as the median absolute deviation calculated on the empirical distribution of the corresponding phase. ${ }^{26}$ Statement of final turning points is finally assessed after checking that a peak (trough) is followed by a trough (peak).

Different methodologies have been used in the literature in order to isolate the business cycle component: Hodrick-Prescott filter, Baxter-King and ChristianoFitzgerald band-pass filters, Beveridge-Nelson decomposition, etc. In what follows we extract the cyclical component of Italian GDP by applying the most commonly used detrending technique in business cycle research, the Hodrick-Prescott filter, with a smoothing parameter equal to 6.25 (see Ravn and Uhlig 2002). The business cycle chronology obtained applying the HP filter to the new Italian GDP series is shown in Table 6 and Fig. 8, where the major phases of contraction in Italy's economic activity, defined as peak-to-trough dates, are represented by shaded grey areas.

\footnotetext{
26 The median absolute deviation is the median of the absolute differences between the data and their median, and provide a robust measure of the dispersion of a variable because little affected by anomalies. Such a measure can be preferred to the most popular standard deviation when data, instead of being normally distributed, are likely to be distributed asymmetrically or to have heavy tails, as it is the case of the empirical distributions of expansion and recession phases of economic activity (see Ormerod and Mounfield 2001; Gaffeo et al. 2003; Di Guilmi et al. 2004; Wright 2005).
} 
Table 6 Italian business cycle chronology, 1861-2011

Source Authors' own

calculations using Baffigi (2013)

estimates

$P$ major peak, at least one median absolute deviation from trend; $T$ major trough, at least one median absolute deviation from trend; $p$ minor peak, less than one median absolute deviation from trend; $t$ minor trough, less than 1 median absolute deviation from trend

\begin{tabular}{|c|c|c|c|c|c|c|c|}
\hline Year & GDP & Year & GDP & Year & GDP & Year & GDP \\
\hline 1861 & & 1901 & $\mathrm{p}$ & 1941 & & 1981 & \\
\hline 1862 & & 1902 & & 1942 & $\mathrm{P}$ & 1982 & \\
\hline 1863 & & 1903 & & 1943 & & 1983 & $\mathrm{~T}$ \\
\hline 1864 & $\mathrm{~T}$ & 1904 & & 1944 & & 1984 & \\
\hline 1865 & $\mathrm{P}$ & 1905 & $\mathrm{t}$ & 1945 & $\mathrm{~T}$ & 1985 & \\
\hline 1866 & & 1906 & & 1946 & & 1986 & \\
\hline 1867 & $\mathrm{~T}$ & 1907 & & 1947 & $\mathrm{P}$ & 1987 & \\
\hline 1868 & & 1908 & $\mathrm{p}$ & 1948 & & 1988 & \\
\hline 1869 & & 1909 & & 1949 & & 1989 & $\mathrm{P}$ \\
\hline 1870 & $\mathrm{P}$ & 1910 & $\mathrm{t}$ & 1950 & & 1990 & \\
\hline 1871 & & 1911 & & 1951 & & 1991 & \\
\hline 1872 & & 1912 & & 1952 & $\mathrm{t}$ & 1992 & \\
\hline 1873 & $\mathrm{~T}$ & 1913 & $\mathrm{P}$ & 1953 & $\mathrm{p}$ & 1993 & $\mathrm{~T}$ \\
\hline 1874 & $\mathrm{P}$ & 1914 & & 1954 & $\mathrm{~T}$ & 1994 & \\
\hline 1875 & & 1915 & $\mathrm{~T}$ & 1955 & $\mathrm{p}$ & 1995 & $\mathrm{p}$ \\
\hline 1876 & & 1916 & & 1956 & & 1996 & \\
\hline 1877 & $\mathrm{~T}$ & 1917 & $\mathrm{P}$ & 1957 & & 1997 & \\
\hline 1878 & $\mathrm{p}$ & 1918 & & 1958 & $\mathrm{t}$ & 1998 & \\
\hline 1879 & $\mathrm{t}$ & 1919 & & 1959 & & 1999 & $\mathrm{t}$ \\
\hline 1880 & & 1920 & & 1960 & & 2000 & \\
\hline 1881 & $\mathrm{P}$ & 1921 & $\mathrm{~T}$ & 1961 & & 2001 & $\mathrm{P}$ \\
\hline 1882 & & 1922 & & 1962 & & 2002 & \\
\hline 1883 & & 1923 & & 1963 & $\mathrm{P}$ & 2003 & \\
\hline 1884 & $\mathrm{~T}$ & 1924 & & 1964 & & 2004 & \\
\hline 1885 & & 1925 & $\mathrm{P}$ & 1965 & $\mathrm{~T}$ & 2005 & $\mathrm{~T}$ \\
\hline 1886 & & 1926 & & 1966 & & 2006 & \\
\hline 1887 & $\mathrm{P}$ & 1927 & $\mathrm{~T}$ & 1967 & & 2007 & $\mathrm{P}$ \\
\hline 1888 & & 1928 & & 1968 & & 2008 & \\
\hline 1889 & $\mathrm{~T}$ & 1929 & $\mathrm{P}$ & 1969 & & 2009 & $\mathrm{~T}$ \\
\hline 1890 & & 1930 & & 1970 & $\mathrm{P}$ & 2010 & \\
\hline 1891 & & 1931 & $\mathrm{~T}$ & 1971 & & 2011 & \\
\hline 1892 & & 1932 & $\mathrm{p}$ & 1972 & $\mathrm{~T}$ & & \\
\hline 1893 & & 1933 & & 1973 & & & \\
\hline 1894 & & 1934 & $\mathrm{t}$ & 1974 & $\mathrm{P}$ & & \\
\hline 1895 & $\mathrm{p}$ & 1935 & $\mathrm{p}$ & 1975 & $\mathrm{~T}$ & & \\
\hline 1896 & & 1936 & $\mathrm{t}$ & 1976 & $\mathrm{p}$ & & \\
\hline 1897 & $\mathrm{t}$ & 1937 & & 1977 & & & \\
\hline 1898 & & 1938 & & 1978 & $\mathrm{t}$ & & \\
\hline 1899 & & 1939 & & 1979 & & & \\
\hline 1900 & & 1940 & & 1980 & $\mathrm{P}$ & & \\
\hline
\end{tabular}


Table 7 Italian business cycle statistics, 1861-2011

\begin{tabular}{llllllll}
\hline & $\begin{array}{l}\text { Entire } \\
\text { sample }\end{array}$ & $\begin{array}{l}\text { Excluding } \\
\text { wars }\end{array}$ & $1861-1913$ & $1922-1939$ & $1951-1974$ & $1975-2001$ & 2002-2011 \\
\hline Years & 151 & 132 & 53 & 18 & 24 & 27 & 10 \\
Cycles & 18 & 13 & 5 & 1 & 2 & 2 & 1 \\
Duration $^{\mathrm{a}}$ & & & & & & & \\
Average $^{\mathrm{b}}$ & 8 & 6 & 5 & 4 & 9 & 9 & 4 \\
Maximum $^{2}$ & 26 & 12 & 7 & 4 & 11 & 10 & 4 \\
Minimum $^{2}$ & 3 & 3 & 3 & 4 & 7 & 8 & 4 \\
Amplitude $^{\mathrm{c}}$ & & & & & & & \\
Average & 6.79 & 4.27 & 4.51 & 6.62 & 3.32 & 3.18 & 5.62 \\
Maximum $^{3}$ & 32.94 & 8.35 & 8.35 & 6.62 & 3.36 & 3.50 & 5.62 \\
Minimum & 2.08 & 2.08 & 2.60 & 6.62 & 3.28 & 2.86 & 5.62 \\
\hline
\end{tabular}

Source Authors' own calculations using Baffigi (2013) estimates

a The duration of a complete business cycle is measured by the number of years separating two consecutive troughs

${ }^{b}$ Rounded to the nearest integer

$\mathrm{c}$ The amplitude is measured by the vertical distance between peak and trough of GDP cyclical deviations from the HP trend; all amplitude values are multiplied by 100

The business cycle chronology obtained with the new GDP series differs only marginally from the previous ones, ${ }^{27}$ with such differences mainly referring to several minor peaks and troughs sparse throughout the sample. For example, with respect to Clementi et al. (2012) two additional minor peaks and troughs are detected in the pre-World War I period (between 1895 and 1905) and two major cycles in the early 1930s are now identified as minor (the second one is also slightly anticipated), with the peak before World War II detected in 1942 instead of 1939. Moreover, in the postWorld War II recessionary phase two extra minor cycles are detected between 1952 and $1958 .{ }^{28}$ Finally, as regards the severity of the Great Depression the new series does not provide any evidence of a larger severity, but just a different timing: whereas the old series indicates that the largest reduction in output occurred the year after the crisis, with a reduction also in the following year, the new series suggests that the financial crisis displayed its effects on the real economy only after two years and just once.

The general features of the Italian business cycles in the 1861-2011 period are shown in Table 7.29

\footnotetext{
27 See Delli Gatti et al. (2003, 2005) and Clementi et al. (2012), with the latter applying the same filtering methodology.

28 Two additional differences refer to the 1922-1924 peak-to-trough phase, which is not anymore present, and the 1976-1978 minor peak-to-trough period that is now identified.

${ }^{29}$ A cycle is measured as the number of years between two successive troughs, while within each cyclical phase we define duration as the number of years from peak to trough (or vice versa) and amplitude as the absolute value of the distance from peak to trough (or vice versa).
} 
Over the whole sample there is evidence of 18 cycles, with duration and amplitude equal on average to 8 years and $6.79 \%$ points, respectively. ${ }^{30}$ When we consider different sub-samples, partially drawing on the previous literature, ${ }^{31}$ some interesting features about duration and amplitude of cyclical fluctuations are in evidence. The reduction in frequency and amplitude of business cycle fluctuations from the pre- to post-World War II period is a well-known phenomenon generally explained with the decline of agriculture's shares of total output and employment along the development path of the country. In particular, an interesting similarity emerge between the preWorld War I and interwar periods and the first decade of the new century, since in the last decade both duration and amplitude of cyclical fluctuations have turned back to values close to those of the pre-World War II period. Indeed, at the beginning of the new century the average duration ( 4 years) has more than halved and the average amplitude (5.6\% points) almost doubled with respect to the second half of the previous century. This result is likely to be the consequence of the worst financial crisis and recession that affected the global economy since the 1929 Great Depression.

In order to verify the hypothesis of business cycles asymmetry of the phases we need to investigate the main characteristics of expansions and recessions, that is duration, amplitude and steepness, the last one being represented by the ratio between amplitude and duration (Sichel 1993). The results in Table 8 confirm standard findings about the asymmetry of expansions and contractions.

Indeed, since on average expansions are generally longer than contractions ( 5 versus 3 years) but cyclical amplitude is almost identical, ${ }^{32}$ contractions tend to be sharper than expansions - 0.023 versus 0.014 . Such asymmetric pattern of business cycle fluctuations is mainly determined by two exceptionally long expansion periods, 18891913 and 1931-1942, which increase significantly the average length of expansions in the pre-World War II period, otherwise characterized by expansions and contractions with similar length.

\subsection{Business Cycles Co-movements}

A key feature of modern business cycle analysis concerns the analysis of the patterns of co-movements of macroeconomic variables with output at typical business cycle frequencies. In this sub-section, we investigate the cyclical properties of several aggregate variables in terms of variability, persistence and co-movements with output. Such properties are analyzed over the whole sample and also across several sub-periods as previously detected in Sect. 3.

Table 9 reports the standard deviation for the cyclical components of total value added and its sectoral components, as well as of GDP and several macroeconomic variables.

Three main features emerge from the analysis of the historical pattern of the volatility of cyclical components: in the interwar period-a period characterized by great

\footnotetext{
30 By excluding war periods, these average values reduce to 6 years and $4.27 \%$ points, respectively.

31 In addition to the classical pre-World War I and interwar periods, we split the post-World War II period into two sub-samples, the pre- and post-oil shocks periods, and finally consider the last decade separately.

32 This result is a consequence of the "growth rate" cycle definition.
} 
Table 8 Italian business cycle asymmetries, 1861-2011

\begin{tabular}{|c|c|c|c|c|c|c|c|c|c|}
\hline \multicolumn{2}{|c|}{ Turning point } & \multicolumn{2}{|c|}{$\mathrm{GDP}^{\mathrm{a}}$} & \multicolumn{2}{|c|}{ Duration $^{b}$} & \multicolumn{2}{|c|}{ Amplitude $^{\mathrm{c}}$} & \multicolumn{2}{|c|}{ Steepness ${ }^{\mathrm{d}}$} \\
\hline \multirow[t]{2}{*}{ Peak } & Trough & Peak & Trough & Contr. & Exp. & Contr. & Exp. & Contr. & Exp. \\
\hline & 1864 & & 0.01 & & 1 & & 0.05 & & 0.05 \\
\hline 1865 & 1867 & 0.04 & 0.04 & 2 & 3 & 0.08 & 0.07 & 0.04 & 0.02 \\
\hline 1870 & 1873 & 0.02 & 0.02 & 3 & 1 & 0.05 & 0.04 & 0.02 & 0.04 \\
\hline 1874 & 1877 & 0.02 & 0.01 & 3 & 4 & 0.03 & 0.02 & 0.01 & 0.01 \\
\hline 1881 & 1884 & 0.01 & 0.02 & 3 & 3 & 0.03 & 0.04 & 0.01 & 0.01 \\
\hline 1887 & 1889 & 0.02 & 0.01 & 2 & 24 & 0.04 & 0.06 & 0.02 & 0.00 \\
\hline 1913 & 1915 & 0.04 & 0.05 & 2 & 2 & 0.10 & 0.09 & 0.05 & 0.04 \\
\hline 1917 & 1921 & 0.03 & 0.05 & 4 & 4 & 0.09 & 0.09 & 0.02 & 0.02 \\
\hline 1925 & 1927 & 0.03 & 0.03 & 2 & 2 & 0.07 & 0.08 & 0.03 & 0.04 \\
\hline 1929 & 1931 & 0.04 & 0.02 & 2 & 11 & 0.06 & 0.11 & 0.03 & 0.01 \\
\hline 1942 & 1945 & 0.09 & 0.24 & 3 & 2 & 0.33 & 0.32 & 0.11 & 0.16 \\
\hline 1947 & 1954 & 0.08 & 0.01 & 7 & 9 & 0.09 & 0.03 & 0.01 & 0.00 \\
\hline 1963 & 1965 & 0.01 & 0.02 & 2 & 5 & 0.03 & 0.04 & 0.02 & 0.01 \\
\hline 1970 & 1972 & 0.02 & 0.02 & 2 & 2 & 0.03 & 0.04 & 0.02 & 0.02 \\
\hline 1974 & 1975 & 0.03 & 0.03 & 1 & 5 & 0.06 & 0.05 & 0.06 & 0.01 \\
\hline 1980 & 1983 & 0.02 & 0.01 & 3 & 6 & 0.04 & 0.03 & 0.01 & 0.00 \\
\hline 1989 & 1993 & 0.01 & 0.02 & 4 & 8 & 0.03 & 0.03 & 0.01 & 0.00 \\
\hline 2001 & 2005 & 0.01 & 0.01 & 4 & 2 & 0.02 & 0.03 & 0.01 & 0.02 \\
\hline 2007 & 2009 & 0.02 & 0.03 & 2 & & 0.06 & & 0.03 & \\
\hline \multicolumn{2}{|c|}{ Average $^{\mathrm{e}}$} & 0.03 & 0.04 & 3 & 5 & 0.07 & 0.07 & 0.03 & 0.03 \\
\hline
\end{tabular}

Source Authors' own calculations using Baffigi (2013) estimates

a The values refer to the cyclical deviations of the variable from the HP trend in correspondence of the business cycle turning points-as for the cyclical deviations corresponding to trough years, the absolute values are reported

${ }^{b}$ The duration of a business cycle contraction (expansion) is measured by the number of years separating a peak (trough) from the adjacent trough (peak)

c The amplitude of business cycle contractions and expansions is measured, respectively, by the peak-totrough and trough-to-peak vertical distance of GDP cyclical deviations from the HP trend

$\mathrm{d}$ The steepness of business cycle phases is calculated as the amplitude divided by the duration

e Average duration rounded to the nearest integer

instability at both national and international level because of the changing exchange rate regimes and the effects of the Great Depression (Bergman et al. 1998) - all aggregates, with the exception of public consumption, display the highest volatility amongst all sub-samples. Most macroeconomic variables, except for employment and productivity, display high volatility also in the pre-World War I period, so that oscillations of the cyclical components of most variables in the post-World War II period are largely reduced in comparison to earlier periods. The only exception to such behaviour is provided by the balance of trade variables, whose volatility remains remarkably high (generally three to five times as volatile as GDP) and quite stable also in the post-World War II period. 
Table 9 Economic fluctuations in Italy: standard deviation for some aggregates, 1861-2011

\begin{tabular}{|c|c|c|c|c|c|c|c|}
\hline & $\begin{array}{l}\text { Entire } \\
\text { sample }\end{array}$ & $\begin{array}{l}\text { Excluding } \\
\text { wars }\end{array}$ & 1861-1913 & 3 1922-1939 & $1951-1974^{a}$ & 1975-2001 & 2002-2011 \\
\hline \multicolumn{8}{|c|}{ Total and sectoral value added ${ }^{b}$} \\
\hline $\begin{array}{l}\text { Total value } \\
\text { added }\end{array}$ & 0.03 & 0.02 & 0.01 & 0.03 & 0.01 & 0.01 & 0.01 \\
\hline Agriculture & 0.04 & 0.03 & 0.03 & 0.06 & 0.04 & 0.02 & 0.02 \\
\hline Industry & 0.07 & 0.03 & 0.02 & 0.06 & 0.02 & 0.02 & 0.03 \\
\hline Private services & 0.03 & 0.02 & 0.02 & 0.03 & 0.01 & - & - \\
\hline $\begin{array}{l}\text { Public } \\
\text { administration }\end{array}$ & 0.09 & 0.05 & 0.05 & 0.07 & 0.02 & - & - \\
\hline Total services & 0.03 & 0.02 & 0.01 & 0.03 & 0.01 & 0.01 & 0.01 \\
\hline \multicolumn{8}{|c|}{ GDP and main expenditure components } \\
\hline GDP & 0.03 & 0.02 & 0.02 & 0.03 & 0.01 & 0.01 & 0.02 \\
\hline $\begin{array}{l}\text { Private } \\
\text { consumption }\end{array}$ & 0.03 & 0.02 & 0.03 & 0.05 & 0.01 & 0.01 & 0.01 \\
\hline $\begin{array}{l}\text { Public } \\
\text { consumption }\end{array}$ & 0.09 & 0.06 & 0.08 & 0.06 & 0.02 & 0.02 & 0.01 \\
\hline $\begin{array}{l}\text { Total fixed } \\
\text { investments }\end{array}$ & 0.08 & 0.04 & 0.05 & 0.06 & 0.03 & 0.03 & 0.04 \\
\hline Exports & 0.20 & 0.07 & 0.07 & 0.11 & 0.05 & 0.04 & 0.07 \\
\hline Imports & 0.12 & 0.08 & 0.06 & 0.15 & 0.07 & 0.06 & 0.08 \\
\hline \multicolumn{8}{|c|}{ Labour market aggregates } \\
\hline Employment & 0.01 & 0.01 & 0.01 & 0.01 & 0.01 & 0.01 & 0.01 \\
\hline Real wages & 0.04 & 0.03 & 0.03 & 0.04 & 0.01 & 0.01 & 0.01 \\
\hline $\begin{array}{l}\text { Labour } \\
\text { productivity }\end{array}$ & 0.01 & 0.01 & 0.01 & 0.01 & 0.01 & 0.01 & 0.01 \\
\hline \multicolumn{8}{|l|}{ Prices } \\
\hline GDP deflator & 0.06 & 0.03 & 0.03 & 0.05 & 0.02 & 0.01 & 0.00 \\
\hline
\end{tabular}

The standard deviation is calculated for the cyclical components of the series obtained with the HP filter Source: Authors' own calculations using Baffigi (2013) and Giordano and Zollino (2012) estimates

a $1951-1970$ for public administration and private services

b Value added historical data for public administration and private services are only available until 1970

In the first column of Table 10 we report the first-order autocorrelation values for GDP, as they provide a measure of the degree of persistence of output fluctuations. The comparison of GDP autocorrelation across sub-samples indicates that a structural change between pre- and post-World War II periods has taken place. The first-order autocorrelation of GDP displays no persistence in the pre-World War I and interwar periods and a positive degree of persistence in the second half of the previous century. Interestingly, and similarly to what occurs to GDP volatility, GDP autocorrelation values turns to pre-World War II values in the first decade of the current century. ${ }^{33}$

\footnotetext{
33 The results in the last decade of the sample need to be interpreted with caution because of the common shock represented by the recent 2007-8 financial crisis.
} 
Table 10 Economic fluctuations in Italy: cross-correlations for some aggregates, 1861-2011

\begin{tabular}{|c|c|c|c|c|c|c|c|}
\hline & \multirow[t]{2}{*}{ Lag } & \multicolumn{6}{|c|}{ Total and sectoral value added ${ }^{\mathrm{a}}$} \\
\hline & & $\begin{array}{l}\text { Total } \\
\text { value } \\
\text { added }^{\text {b }}\end{array}$ & Agriculture & Industry & $\begin{array}{l}\text { Private } \\
\text { services }\end{array}$ & $\begin{array}{l}\text { Public } \\
\text { administration }\end{array}$ & $\begin{array}{l}\text { Total } \\
\text { services }\end{array}$ \\
\hline \multirow{3}{*}{$\begin{array}{l}\text { Entire } \\
\text { sample }\end{array}$} & -1 & 0.32 & -0.12 & 0.51 & 0.23 & 0.38 & 0.32 \\
\hline & 0 & 1.00 & 0.52 & 0.85 & 0.83 & 0.58 & 0.80 \\
\hline & 1 & 0.32 & -0.01 & 0.20 & 0.53 & 0.38 & 0.50 \\
\hline \multirow{3}{*}{$\begin{array}{l}\text { Excluding } \\
\text { wars }\end{array}$} & -1 & 0.03 & -0.01 & 0.10 & -0.01 & -0.23 & -0.08 \\
\hline & 0 & 1.00 & 0.59 & 0.63 & 0.63 & 0.15 & 0.58 \\
\hline & 1 & 0.03 & -0.33 & 0.29 & 0.24 & 0.25 & 0.27 \\
\hline \multirow[t]{3}{*}{$1861-1913$} & -1 & 0.07 & 0.30 & -0.03 & -0.14 & -0.50 & -0.31 \\
\hline & 0 & 1.00 & 0.69 & 0.29 & 0.52 & 0.36 & 0.54 \\
\hline & 1 & 0.07 & -0.41 & 0.36 & 0.43 & 0.51 & 0.53 \\
\hline \multirow[t]{3}{*}{$1922-1939$} & -1 & -0.10 & -0.25 & 0.16 & 0.05 & 0.06 & 0.04 \\
\hline & 0 & 1.00 & 0.70 & 0.67 & 0.84 & -0.11 & 0.71 \\
\hline & 1 & -0.10 & -0.43 & 0.28 & 0.12 & -0.11 & 0.07 \\
\hline \multirow[t]{3}{*}{$1951-1970$} & -1 & 0.24 & 0.10 & 0.17 & 0.35 & -0.11 & 0.31 \\
\hline & 0 & 1.00 & 0.32 & 0.89 & 0.65 & 0.34 & 0.45 \\
\hline & 1 & 0.24 & -0.23 & 0.41 & 0.22 & 0.26 & 0.12 \\
\hline \multirow[t]{3}{*}{$1971-2001$} & -1 & 0.30 & 0.30 & 0.19 & - & - & 0.35 \\
\hline & 0 & 1.00 & 0.34 & 0.90 & - & - & 0.93 \\
\hline & 1 & 0.30 & -0.09 & 0.31 & - & - & 0.28 \\
\hline \multirow[t]{5}{*}{$2002-2011$} & -1 & 0.00 & -0.28 & 0.07 & - & - & -0.08 \\
\hline & 0 & 1.00 & 0.41 & 0.98 & - & - & 0.97 \\
\hline & 1 & 0.00 & 0.30 & -0.03 & - & - & 0.01 \\
\hline & Lag & \multicolumn{6}{|c|}{ GDP and main expenditure components } \\
\hline & & $\mathrm{GDP}^{\mathrm{b}}$ & $\begin{array}{l}\text { Private } \\
\text { consumption }\end{array}$ & $\begin{array}{l}\text { Public } \\
\text { consumption }\end{array}$ & $\begin{array}{l}\text { Total fixed } \\
\text { investment }\end{array}$ & Exports & Imports \\
\hline \multirow{3}{*}{$\begin{array}{l}\text { Entire } \\
\text { sample }\end{array}$} & -1 & 0.37 & 0.15 & 0.07 & 0.52 & 0.27 & 0.30 \\
\hline & 0 & 1.00 & 0.68 & 0.24 & 0.55 & 0.77 & 0.42 \\
\hline & 1 & 0.37 & 0.29 & 0.19 & -0.05 & 0.40 & 0.29 \\
\hline \multirow{3}{*}{$\begin{array}{l}\text { Excluding } \\
\text { wars }\end{array}$} & -1 & 0.07 & 0.12 & -0.19 & 0.07 & 0.02 & 0.08 \\
\hline & 0 & 1.00 & 0.73 & -0.05 & 0.43 & 0.33 & 0.48 \\
\hline & 1 & 0.07 & -0.16 & 0.22 & 0.26 & 0.05 & -0.06 \\
\hline \multirow[t]{3}{*}{$1861-1913$} & -1 & 0.08 & 0.40 & -0.48 & 0.10 & -0.19 & 0.28 \\
\hline & 0 & 1.00 & 0.66 & 0.17 & 0.38 & 0.03 & 0.20 \\
\hline & 1 & 0.08 & -0.11 & 0.38 & 0.11 & 0.30 & 0.11 \\
\hline
\end{tabular}


Table 10 continued

\begin{tabular}{|c|c|c|c|c|c|c|}
\hline & \multirow[t]{2}{*}{ Lag } & \multicolumn{5}{|c|}{ GDP and main expenditure components } \\
\hline & & $\mathrm{GDP}^{\mathrm{b}}$ & $\begin{array}{l}\text { Private } \\
\text { consumption }\end{array}$ & $\begin{array}{l}\text { Public } \\
\text { consumption }\end{array}$ & $\begin{array}{l}\text { Total fixed } \\
\text { investment }\end{array}$ & Exports Imports \\
\hline \multirow[t]{3}{*}{ 1922-1939 } & -1 & -0.03 & 0.05 & -0.10 & 0.01 & 0.22 \\
\hline & 0 & 1.00 & 0.87 & -0.59 & 0.24 & 0.57 \\
\hline & 1 & -0.03 & -0.29 & -0.29 & -0.29 & $-0.29-0.29$ \\
\hline \multirow[t]{3}{*}{ 1951-1974 } & -1 & 0.33 & 0.06 & 0.00 & 0.16 & 0.11 \\
\hline & 0 & 1.00 & 0.38 & -0.53 & 0.70 & 0.23 \\
\hline & 1 & 0.33 & -0.18 & -0.18 & 0.42 & -0.22 \\
\hline \multirow[t]{3}{*}{$1975-2001$} & -1 & 0.33 & 0.11 & 0.07 & 0.07 & 0.20 \\
\hline & 0 & 1.00 & 0.79 & 0.40 & 0.73 & 0.32 \\
\hline & 1 & 0.33 & 0.30 & 0.59 & 0.61 & -0.18 \\
\hline \multirow[t]{5}{*}{ 2002-2011 } & -1 & 0.08 & 0.19 & 0.27 & 0.09 & 0.12 \\
\hline & 0 & 1.00 & 0.97 & -0.42 & 0.98 & 0.98 \\
\hline & 1 & 0.08 & 0.01 & -0.38 & 0.08 & $\begin{array}{ll}0.01 & -0.09 \\
\end{array}$ \\
\hline & Lag & \multicolumn{3}{|c|}{ GDP and labour market aggregates } & Lag & GDP and prices \\
\hline & & Employment & $\begin{array}{l}\text { Real } \\
\text { wages }\end{array}$ & $\begin{array}{l}\text { Labour } \\
\text { productivity }\end{array}$ & & Implicit deflator \\
\hline \multirow{3}{*}{$\begin{array}{l}\text { Entire } \\
\text { sample }\end{array}$} & -1 & -0.18 & -0.01 & 0.38 & -1 & 0.10 \\
\hline & 0 & 0.06 & 0.20 & 0.96 & 0 & -0.24 \\
\hline & 1 & 0.09 & 0.33 & 0.32 & 1 & -0.45 \\
\hline \multirow{3}{*}{$\begin{array}{l}\text { Excluding } \\
\text { wars }\end{array}$} & -1 & -0.12 & -0.06 & 0.10 & -1 & -0.05 \\
\hline & 0 & 0.21 & 0.12 & 0.87 & 0 & -0.22 \\
\hline & 1 & 0.09 & 0.21 & 0.01 & 1 & -0.25 \\
\hline \multirow[t]{3}{*}{ 1861-1913 } & -1 & -0.25 & -0.15 & 0.23 & -1 & 0.22 \\
\hline & 0 & -0.06 & 0.34 & 0.88 & 0 & -0.35 \\
\hline & 1 & 0.03 & 0.31 & -0.01 & 1 & -0.44 \\
\hline \multirow[t]{3}{*}{ 1922-1939 } & -1 & -0.01 & 0.04 & -0.09 & -1 & -0.12 \\
\hline & 0 & 0.28 & -0.16 & 0.92 & 0 & -0.03 \\
\hline & 1 & 0.00 & 0.17 & -0.04 & 1 & -0.14 \\
\hline \multirow[t]{3}{*}{ 1951-1970 } & -1 & 0.26 & -0.18 & 0.13 & -1 & -0.58 \\
\hline & 0 & 0.33 & -0.37 & 0.83 & 0 & -0.25 \\
\hline & 1 & 0.31 & -0.14 & 0.17 & 1 & 0.05 \\
\hline \multirow[t]{3}{*}{ 1971-2001 } & -1 & -0.21 & 0.18 & 0.43 & -1 & -0.74 \\
\hline & 0 & 0.34 & 0.47 & 0.71 & 0 & -0.44 \\
\hline & 1 & 0.46 & 0.46 & 0.03 & 1 & 0.07 \\
\hline
\end{tabular}


Table 10 continued

\begin{tabular}{ccccccc}
\hline & Lag & \multicolumn{2}{l}{ GDP and labour market aggregates } & & Lag & \multicolumn{2}{c}{\begin{tabular}{l} 
GDP and prices \\
\cline { 3 - 6 }
\end{tabular}} & Employment & $\begin{array}{l}\text { Real } \\
\text { wages }\end{array}$ & $\begin{array}{l}\text { Labour } \\
\text { productivity }\end{array}$ & & Implicit deflator \\
\hline $2002-2011$ & -1 & -0.28 & 0.30 & 0.00 & -1 & -0.72 \\
& 0 & 0.70 & 0.64 & 0.90 & 0 & -0.55 \\
& 1 & 0.65 & -0.32 & -0.17 & 1 & 0.62 \\
\hline
\end{tabular}

A maximum correlation at lag 0 indicates that the variable has a coincident cyclical behaviour with respect to that of the reference variable (total value added or GDP); a maximum correlation for a lag order $1(-1)$ indicates a variable lagging (leading) of 1 year compared to the reference one

Source Authors' own calculations using Baffigi (2013) and Giordano and Zollino (2012) estimates

a Disaggregation levels for service sector value added are only available up to 1970; from 1971 onwards, the block of 1861-2011 estimates is used-see text and Baffigi (2013, pp. 161-162)

$\mathrm{b}$ The values refer to the autocorrelation of the cyclical component of the variable

Table 10 also shows the pairwise correlation coefficients between the cyclical components of some selected macroeconomic variables and GDP. ${ }^{34}$ The main difference refers to the cyclical behaviour of aggregate demand components between pre- and post-World War II periods. Indeed, in the latter period the findings conform quite well to those obtained in the standard international business cycle literature, while in the pre-World War II period the results tend to differ widely across sub-samples, except for private consumption and investment. The cyclical behaviour of private consumption is remarkably uniform over different sub-periods, being generally strongly procyclical (procyclical in the period between World War II and the first oil-shock) and coincident with GDP, whereas investment changes from weakly procyclical in the pre-World War II period to strongly procyclical in the post-World War II period. As to public expenditure, it is mostly countercyclical, with exceptions in the pre-World War I period and the last quarter of the previous century, where government spending is acyclical and procyclical respectively. Finally, net exports are acyclical in the pre-World War II period because of the role of protectionist trade policies-such as the 1887 tariff and the autarchy policy of the Fascist regime in the interwar period-with evidence of growth-led exports, and countercyclical in the post-World War II period since imports are strongly procyclical and exports only weakly procyclical.

In addition to expenditure variables, labour market and price variables are also examined - see the bottom panel of the same table. Both labour productivity and implicit price deflator variables display a remarkably stable strongly procyclical and countercyclical behaviour, respectively, in almost every period (unique exception is the price deflator in the interwar period). Moreover, the implicit price deflator tends to negatively lead the cycle in the post-World War II period. Finally, while employment is

\footnotetext{
34 From the value of the contemporaneous correlation coefficient we can define a variable as procyclical, acyclical or countercyclical, and according to the timing of the maximum correlation coefficient we can say if that variable is leading, synchronous or lagging the cycle. Specifically, we define procyclical a series whose contemporaneous correlation with GDP is $>0.3$ (strongly pro-cyclical if $>0.60$ ), acyclical when it is between -0.3 and 0.3 , and countercyclical for values lower than -0.3 . In addition, a series is defined as leading, synchronous and lagging if the largest cross-correlation value is in entry $t-1, t$ or $t+1$ respectively.
} 
moderately procyclical for most of the time-from post-World War I to the end of the previous century-real wages alternate periods of positive and negative relationships with GDP, the latter ones being concentrated in the periods before and after World War II. A unique and straightforward pattern of correlation distinguishes the last decade of the sample: there is a strong procyclical relationship with GDP for all variables save for government spending and implicit price deflator, which are countercyclical.

The same analysis is performed on total and sectoral value added as shown in the top panel of Table 10. Not unexpectedly, given the large weight of the agricultural sector in the pre-World War II period, we find that the agricultural sector is mostly correlated with total value added, with such correlation decreasing throughout the sample. A similar but inverted pattern, i.e. increasing strong correlation, is observed for the industry and services sector, although for the latter sector the increasing pattern is temporarily reduced in the post-World War II period.

\section{Concluding remarks}

In this paper we revisit the main features of economic growth and cycles in Italy in the post-Unification period by using the new dataset provided in Baffigi (2013). As an effect of the revision of GDP estimates, for the pre-World War I period no structural break is in evidence anymore at the turn of the nineteenth century, casting doubts on the occurrence of the "take-off" interpretation of the historical literature. By contrast, two structural breaks are detected in the post-World War II period-the first in the mid-1970s, the latter at the turn of the twentieth century-as a consequence of the progressive reduction of GDP growth rates following the "productivity slowdown".

The analysis of the contributions to growth by final demand components indicates that private consumption and total fixed investment have been the main determinants of GDP growth throughout the period. Net exports made a positive contribution to growth in the interwar period, as a result of the sharp falling off in import demand, and in the last quarter of the previous century because of the large positive contribution of exports, whereas public spending's contribution to GDP growth is positive only in the post-World War II period. On the side of sectoral contribution to value added and labour productivity growth, the industry and services sectors were by far the main contributing sectors, also because of the positive effect of the reallocation of labour to nonfarm activities. Specifically, the industry and services sectors were the main contributing sectors in the interwar period and in the last quarter of the twentieth century, respectively, whereas the impressive growth of the post-World War II years can be attributed to large productivity increases within both the industry and services sectors.

As regards the sectoral origins of the business cycles, GDP fluctuations are dominated by the short-term variability of agricultural production in the pre-World War II period and by fluctuations of the industrial component in the post-World War II period. The cyclical behaviour of aggregate demand components conform to those evidenced in the standard international business cycle literature in the post-World War II period, while in the pre-World War II period their cyclical pattern tend to differ widely across sub-samples (exceptions are consumption and investments). Specifically, private con- 
sumption and investments are most of the times strongly procyclical and coincident (procyclical after World War II and the first oil shock period), while net exports and government consumption are mostly countercyclical (the first in the post-World War II period and the latter over the World War II period). Finally, as regards labour market aggregates and prices we find that their cyclical behaviour is quite uniform across periods, with the only exception of real wages whose behaviour is very irregular (from weakly procyclical to acyclical, then countercyclical and procyclical again). Indeed, employment is weakly procyclical, labour productivity is always strongly procyclical and prices are mostly countercyclical, with the only exception of the period between the two World Wars.

The analysis of Italy's national historical allows us to reconsider the representative cycle hypothesis implicitly stated in most of the recent literature on business cycle fluctuations (RBC). The results provided in this paper provide evidence contrasting with the hypothesis of RBC models in terms of heterogeneity of business cycle fluctuations in Italy along its developmental path. Business cycles represent complex and, for some aspects, peculiar events (Haberler 1958), ${ }^{35}$ whose analysis requires to reconsider the set of analytical tools beyond the analysis of aggregate data. If this is true, finding business cycle empirical regularities by omitting the factors responsible for the changes in such regularities can generate only partial results.

\section{References}

Ancona A, Bonato L (1996) Ciclo economico e stabilizzazione. La storia recente in un confronto internazionale. Riv Pol Econ 86:3-35

Andrews DWK (1993) Tests for parameter instability and structural change with unknown change point. Econometrica 61:821-856

Andrews DWK, Ploberger W (1994) Optimal tests when a nuisance parameter is present only under the alternative. Econometrica 62:1383-1414

Ardeni PG, Gallegati Mauro (1991) Long-term trends and cycles in the Italian economy (1861-1988). Giorn Econ Ann Econ 50:193-235

Ardeni PG, Gallegati Mauro (1994a) Cicli di crescita nello sviluppo: 1861-1990. In: Ciocca P (ed) Il progresso economico dell'Italia. Permanenze, discontinuità, limiti, Il Mulino, Bologna, pp 109-135

Ardeni PG, Gallegati Mauro (1994b) Crescita e fluttuazioni nell'economia italiana (1861-1913). Una reinterpretazione. Polit Econ 10:119-153

Artis MJ, Marcellino M, Proietti T (2004) Dating the Euro area business cycle. In: Reichlin L (ed) The Euro area business cycle: stylized facts and measurement issues. Centre for Economic Policy Research (CEPR), London, pp 7-33

Baffigi A (2013) National Accounts, 1861-2011. In: Toniolo G (ed) The Oxford handbook of the Italian economy since Unification. Oxford University Press, New York, pp 157-186

Baffigi A (2014) Il PIL per la storia d'Italia. Istruzioni per l'uso, Marsilio Editori, Venice

Baffigi A, Bontempi ME, Golinelli R (2013) Potential output, output gap, and inflation in Italy in the long term (1861-2010): an econometric analysis. Economic History Working Papers (Quaderni di Storia Economica) 29, Bank of Italy, Rome

Bai J, Perron P (1998) Estimating and testing linear models with multiple structural changes. Econometrica $66: 47-78$

Bai J, Perron P (2003) Computation and analysis of multiple structural change models. J Appl Econ 18:1-22 Battilani P, Felice E, Zamagni V (2012) Il valore aggiunto dei servizi a prezzi correnti (1861-1951), Mimeo

\footnotetext{
35 "Each cycle, each period of prosperity and depression, has its special features which are not present in any, or not in many, others. In a sense, each cycle is an historical individual: each is embedded in a social-economic structure of its own" (Haberler 1958, p. 275).
} 
Baumol WJ (1967) Macroeconomics of unbalanced growth: the anatomy of urban crisis. Am Econ Rev $57: 415-426$

Baumol WJ, Blackman SAB, Wolff EN (1985) Unbalanced growth revisited: asymptotic stagnancy and new evidence. Am Econ Rev 75:806-817

Bergman M, Bordo MD, Jonung L (1998) Historical evidence on business cycles: the international experience. In: Fuhrer JC, Schuh S (eds) Beyond shocks: what causes business cycles?. Federal Reserve Bank of Boston, Boston, pp 65-118

Broadberry SN (2005) Appendix 9.1. Italian GDP during World War I. In: Broadberry SN, Harrison M (eds) The economics of World War I. Cambridge University Press, New York, pp 305-309

Broadberry SN, Giordano C, Zollino F (2011), A sectoral analysis of Italy's development, 1861-2011. Economic History Working Papers (Quaderni di Storia Economica) 20, Bank of Italy, Rome

Bry G, Boschan C (1971) Cyclical analysis of time series: selected procedures and computer programs. National Bureau of Economic Research (NBER), New York

Burns AF, Mitchell WC (1946) Measuring business cycles. National Bureau of Economic Research (NBER), New York

Chiarini B (1994) Trends, effetti permanenti e componenti non stazionarie: uno studio disaggregato del prodotto e dell'occupazione italiana. Riv Pol Econ 84:39-80

Checchi D, Rampa G, Rampa L (1997) Fluttuazioni cicliche di medio termine nell'economia italiana del dopoguerra. In: Banca d'Italia (ed) Ricerche quantitative per la politica economica, 1995. Centro stampa della Banca d'Italia, Roma, pp 989-1055

Ciccarelli C, Fenoaltea S (2007) Business fluctuations in Italy, 1861-1913: the new evidence. Explor Econ Hist 44:432-451

Ciocca P (ed) (1994) Il progresso economico dell'Italia. Permanenze, discontinuità, limiti, Il Mulino, Bologna

Ciocca P (2007) Ricchi per sempre? Una storia economica d'Italia (1796-2005). Bollati Boringhieri, Torino

Ciocca P, Toniolo G (eds) (1976) L'economia italiana nel periodo fascista. Il Mulino, Bologna

Clementi F, Gallegati Marco, Gallegati Mauro (2012) Crescita e fluttuazioni economiche: un' analisi di lungo periodo dell'Italia postunitaria, 1861-2009. In: Canullo G, Pettenati P (eds) Sviluppo economico e benessere. Saggi in ricordo di Giorgio Fuà. Edizioni scientifiche italiane, Napoli, pp 187-223

de Avillez R (2012) Sectoral contributions to labour productivity growth in Canada: does the choice of decomposition formula matter? Int Product Monit 24:97-117

De Bonis R, Farabullini F, Rocchelli M, Salvio A (2012) A quantitative look at the Italian banking system: evidence from a new dataset since 1861. Economic History Working Papers (Quaderni di Storia Economica) 26, Bank of Italy, Rome

Delli Gatti D, Gallegati Marco, Gallegati Mauro (2003) Sulla natura e le cause delle fluttuazioni cicliche in Italia (1861-2000). In: Ciocca P, Toniolo G (eds) Storia economica d'Italia. 3. Industrie, mercati, istituzioni. 1. Le strutture dell'economia, Laterza, Roma-Bari, pp 535-578

Delli Gatti D, Gallegati Marco, Gallegati Mauro (2005) On the nature and causes of business fluctuations in Italy, 1861-2000. Explor Econ Hist 42:81-100

Denison EF (1962) The sources of economic growth in the united states and the alternative before US. Supplementary Paper No. 13, Committee for Economic Development, New York

Di Guilmi C, Gaffeo E, Gallegati Mauro (2004) Empirical results on the size distribution of business cycle phases. Phys A Stat Theor Phys 333:325-334

Dumagan JC (2013) A generalized exactly additive decomposition of aggregate labour productivity growth. Rev Income Wealth 59:157-168

Ercolani P (1978) Documentazione statistica di base. In: Fuà G (ed) Lo sviluppo economico in Italia. Storia dell'Economia Italiana negli ultimi cento anni. Volume III-Studi di settore e documentazione di base, 3rd edn. Franco Angeli, Milano, pp 388-472

Federico G (ed) (1994) The economic development of Italy since 1870. Edward Elgar, Aldershot

Federico G (2003) Le nuove stime della produzione agricola italiana, 1860-1910: primi risultati e implicazioni. Riv Stor Econ 19:359-381

Felice E, Carreras A (2012) When did modernization begin? Italy's industrial growth reconsidered in light of new value-added series, 1911-1951. Explor Econ Hist 49:443-460

Fenoaltea S (2005a) La crescita economica dell'Italia postunitaria: le nuove serie storiche. Riv Stor Econ 21:91-121

Fenoaltea S (2005b) The growth of the Italian economy, 1861-1913: preliminary second-generation estimates. Eur Rev Econ Hist 9:273-312 
Fenoaltea S (2006) L'economia italiana dall'Unità alla Grande Guerra. Laterza, Roma-Bari

Fiorito R, Kollintzas T (1994) Stylized facts of business cycles in the G7 from a real business cycles perspective. Eur Econ Rev 38:235-269

Fuà G (ed) (1969) Lo sviluppo economico in Italia. Storia dell'Economia Italiana negli ultimi cento anni. Studi di settore e documentazione di base, vol III, 1st edn. Franco Angeli, Milano

Fuà G (ed) (1978) Lo sviluppo economico in Italia. Storia dell'economia italiana negli ultimi cento anni. Volume III - Studi di settore e documentazione di base, 3rd edn. Franco Angeli, Milan

Fuà G (ed) (1981) Lo sviluppo economico in Italia. Storia dell'Economia Italiana negli ultimi cento anni. Lavoro e reddito, vol I. Franco Angeli, Milano

Gaffeo E, Gallegati Marco (1997) A frequency domain analysis of business cycle in Italy: 1866-1996. Rass Lav ISCO 14:33-50

Gaffeo E, Gallegati Mauro, Giulioni G, Palestrini A (2003) Power laws and macroeconomic fluctuations. Phys A Stat Mech Appl 324:408-416

Gallegati Marco (1996) Testing output stationarity through its supply components: Italy, 1861-1993. Econ Notes 25:249-260

Gallegati Mauro, Stanca LM (1998) Le fluttuazioni economiche in Italia, 1861-1995. Ovvero, il camaleonte e il virus dell'influenza, Giappichelli, Torino

Giannini C, Lanzarotti A, Seghelini M (1995) A traditional interpretation of macroeconomic fluctuations: the case of Italy. Eur J Polit Econ 11:131-155

Giordano C, Zollino F (2012) A historical reconstruction of capital and labour in Italy, 1861-2011, Mimeo

Giugliano F (2011) Crisis? Which crisis? New estimates of industrial value added in Italy during the Great Depression, Mimeo

Golinelli R, Monterastelli M (1990) Un metodo di lavoro per la ricostruzione di serie storiche compatibili con la nuova contabilità nazionale (1951-1989). Nota di lavoro 9001, Prometeia, Bologna

Haberler G (1958) Prosperity and depression: a theoretical analysis of cyclical movements. Allen \& Unwin, London

ISTAT (1957) Indagine statistica sullo sviluppo del reddito nazionale in Italia dal 1861 al 1956. Ann Stat VIII, vol IX, Roma

Lequiller F, Blades D (2007) Understanding national accounts. OECD Publishing, Paris

Lucas RE (1977) Understanding business cycles. Carnegie-Rochester Conf Ser Public Policy 5:7-29

Maddison A (1991) A revised estimate of Italian economic growth, 1861-1989. BNL Q Rev 177:225-241

Mattesini F, Quintieri B (1997) Italy and the Great Depression: an analysis of the Italian economy, 19291936. Explor Econ Hist 34:265-294

Nordhaus WD (2002) Productivity growth and the new economy. Brook Pap Econ Act 33:211-265

Onofri P, Paruolo P, Salituro B (1992) Sulle fonti delle fluttuazioni dell'economia italiana: una analisi con sistemi VAR strutturali. Riv Pol Econ 82:33-66

Ormerod P, Mounfield C (2001) Power law distribution of the duration and magnitude of recessions in capitalist economies: breakdown of scaling. Phys A Stati Mech Appl 293:573-582

Rappoport P, Reichlin L (1989) Segmented trends and non-stationary time series. Econ J 99:168-177

Ravn MO, Uhlig H (2002) On adjusting the Hodrick-Prescott filter for the frequency of observations. Rev Econ Stat 84:371-375

Rey GM (ed) (1991) I conti economici dell'Italia. I. Una sintesi delle fonti ufficiali. 1890-1970, Laterza, Roma-Bari

Rossi N, Sorgato A, Toniolo G (1993) I conti economici italiani: una ricostruzione statistica, 1890-1990. Riv di Stor Econ 10:1-47

Schlitzer G (1996) Business cycles in Italy: a statistical investigation. Eur J Polit Econ 11:683-698

Sichel DE (1993) Business cycle asymmetry: a deeper look. Econ Inq 31:224-236

Stanca LM (1996) La misurazione del ciclo economico, aspetti metodologici e regolarità empiriche per l'economia italiana (1960-1993). Giorn Econ Ann Econ 51:211-241

Stock JH, Watson MW (1999) Business cycle fluctuations in US macroeconomic time series. In: Taylor JB, Woodford M (eds) Handbook of macroeconomics, vol 1A, 1st edn. North-Holland, Amsterdam, pp 3-64

Syrquin M (1984) Resource allocation and productivity growth. In: Syrquin M, Taylor L, Westphal LE (eds) Economic structure performance-essays in honor of Hollis B. Chenery. Academic Press, Orlando, pp 75-101

Tang J, Wang W (2004) Sources of aggregate labour productivity growth in Canada and the United States. Can J Econ 37:421-444 
Temin P (1998) The causes of American business cycles: an essay in economic historiography. In: Fuhrer JC, Schuh S (eds) Beyond shocks: what causes business cycles?. Federal Reserve Bank of Boston, Boston, pp 37-59

Toniolo G (ed) (1978) L'economia italiana 1861-1940. Laterza, Bari

Toniolo G (1988) Storia economica dell'Italia liberale (1850-1918). Il Mulino, Bologna

Wright I (2005) The duration of recessions follows an exponential not a power law. Phys A Stat Mech Appl 345:608-610

Zamagni V (1993) The economic history of Italy, 1860-1990: recovery after decline. Clarendon Press, Oxford

Zamagni V (2007) Introduzione alla storia economica d'Italia. Il Mulino, Bologna

Zeileis A, Kleiber C (2005) Validating multiple structural changes models-a case study. J Appl Econ 20:685-690

Zeileis A, Kleiber C, Krämer W, Hornik K (2003) Testing and dating of structural changes in practice. Comput Stat Data Anal 44:109-123

Zeileis A, Leisch F, Hornik K, Kleiber C (2002) strucchange: an R package for testing for structural change in linear regression models. J Stat Softw 7:1-38 